\title{
The reinterpretation of the Cova Negra archaeological and stratigraphical sequence and its implications in the understanding of the Middle Palaeolithic Iberian Peninsula
}

\author{
Aleix Eixea ${ }^{\mathrm{a}, *}$, Isabela Oltra ${ }^{\mathrm{a}}$ M. Mercè Bergadà \\ ${ }^{a}$ Departament de Prehistòria, Arqueologia i Història Antiga, Universitat de València, Blasco Ibáñez, 28, 46010, València, Spain \\ ${ }^{\mathrm{b}}$ SERP. Departament d'Història i Arqueologia, Universitat de Barcelona, C/ Montalegre 6, 08001, Barcelona, Spain
}

\section{A R T I C L E I N F O}

Keywords:

Lithic industry

Taphonomy

Stratigraphy

Middle palaeolithic

Iberian peninsula

\begin{abstract}
A B S T R A C T
This paper presents new data from the reinterpretation of the Cova Negra sequence from a chronological and stratigraphic perspective. The primary aim is to reorder the lithic industry from the excavations of the 1950s in light of the stratigraphic sequence, paying particular attention to raw materials, knapping methods and tools. The reconstruction, carried out from a taphonomic perspective, is specified in sectors B, C and F, and the ar- chaeological levels and the included material are adjusted to the stratigraphic levels. Although the number of remains involved in the proposed chronology is reduced in relation to previous work, it is an arrangement that relies on a more precise chronostratigraphic framework. With these data, it is possible to discuss the techno- typological evolution of the site, initiated around the MIS 9 and which extends during a considerable portion of the Upper Pleistocene. In this sense, the data provided by Cova Negra offer the opportunity to examine the emergence of new technical strategies during a crucial period-the transition from the Lower to Middle Palaeolithic - and the development of the Middle Palaeolithic in the important geographical area of the Iberian Peninsula.
\end{abstract}

\section{Introduction}

From the end of the Middle Pleistocene (between MIS 9 and 5), there is a change in the lithic industries of continental Europe from the UpperAcheulean (UA) to the Early Middle Palaeolithic (EMP). This is a tran- sition between lithic complexes in which the façonnage is dominant (bi-facial tools, cleavers, etc.) and the production focuses on obtaining large flakes to those which the tooling is made ("Large Cutting Tools" in- dustries) (Sharon, 2010; Sharon and Barsky, 2016; Baena et al., 2018) towards assemblages consisting mainly of cores and flake tools (Jaubert, 1999; Villa, 2009; Scott, 2010; Santonja and Pérez-González, 2010; Richter, 2011; Moncel et al., 2012; Santonja et al., 2014). The presence of both techno-complexes during the same chronological period suggests the coexistence of two different technical traditions that have important implications for the study of human evolution and population dynamics, both in Europe and Africa (Sharon, 2011; Bar-Yosef and BelferCohen, 2013; Santonja et al., 2016; Méndez-Quintas et al., 2019).

To address this problem, south-western Europe, and the southern region in particular, constitutes one of the most interesting and rich location in terms of sites with extensive stratigraphies and dates (Turq,
1992; Moncel, 1999; Rodríguez and Lozano, 1999; De Lumley et al., 2004; Moncel et al., 2005; Fernandez-Peris, 2007; Bourguignon et al., 2008; Colonge et al., 2010; Santonja and Pérez-González, 2010; Brenet, 2011; Moncel et al., 2011; Ollé et al., 2013). This mean that this area presents specific regional scenarios and also illustrates the wide varia- bility that exists during this period, both chronologically and spatially. For example, the documented exploitation processes are diverse in southwestern France from MIS 8 onward. This includes systems that range from more expedient to those with greater elaboration, such as Levallois productions (e.g. laminar, discoid or SSDA on anvil) or the façonnage of tools and macro-tools (Delpech et al., 1995; Turq, 2000; Jaubert, 2002; Bourguignon et al., 2006, 2008; Brenet, 2011). This

diversity in lithic production and its objectives shows the coexistence of well differentiated knapping strategies and façonnage schemes and, in some cases, are associated with mixed compositions (Boëda, 1991; Chevrier, 2006; Delagnes et al., 2007). The observations carried out based on the technology, typology, supply of raw materials and use of space do not show significant differences between the end of the Acheulean and the beginning of the Middle Palaeolithic. There is only progressive changes and variations on the same basis that are much 

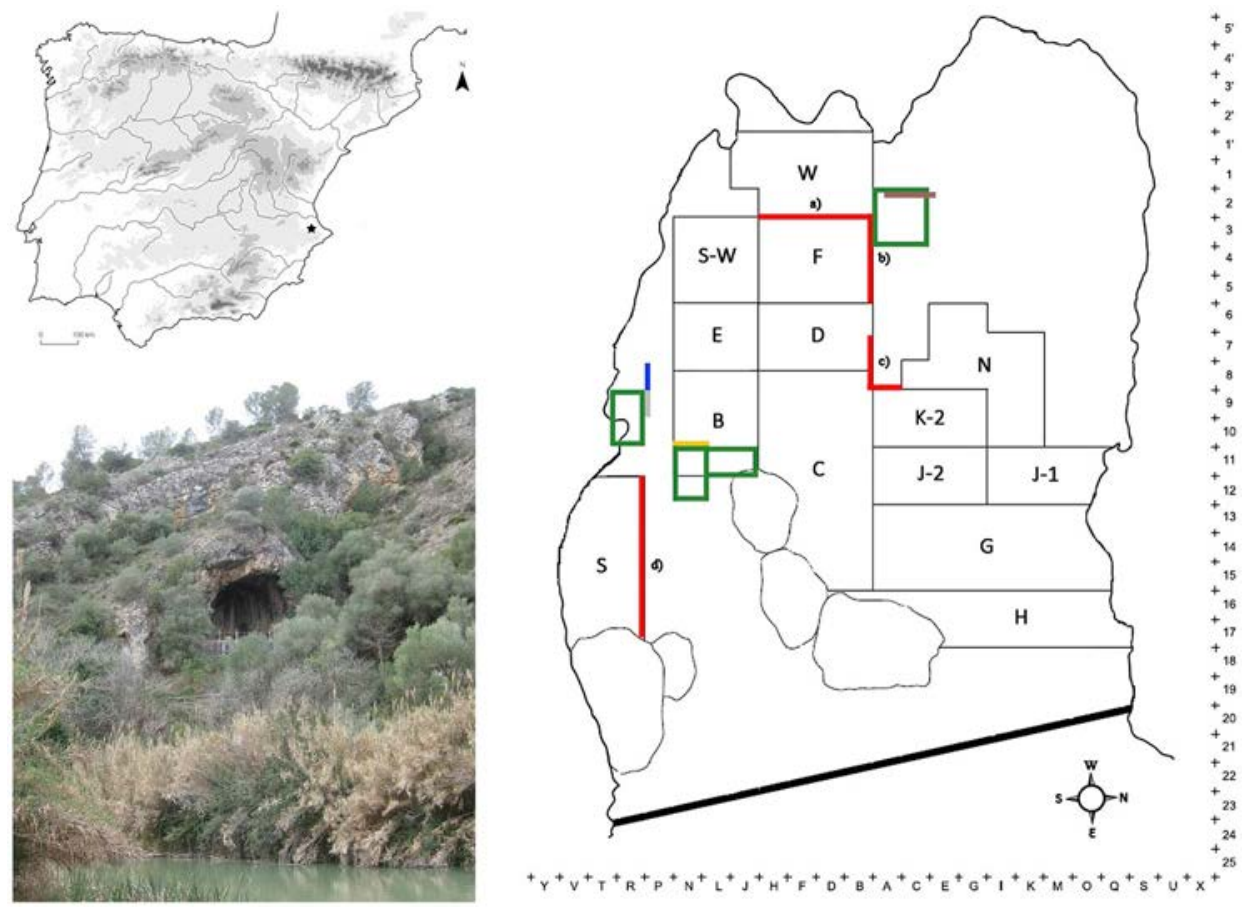

Fig. 1. Site location and general plan of the cavity indicating the excavated sectors. Sectors B, C and F are those treated in this work (red lines): a) Distal frontal profile (West sector); b) Left sagittal profile (sector F); c) Right sagittal profile (South sector), distal frontal (West sector) and left sagittal (sector C); d) Right sa- gittal (South sector) coinciding practically with the right sagittal profile (sector B). Excavated grid-squares are indicated in green and the de- scribed profiles are indicated in blue (P-8), grey (P-9), yellow (N-11) and brown (C-2). (For interpretation of the references to colour in this figure legend, the reader is referred to the Web version of this article.) more marked from MIS 4 and 3 with the emergence of well-differ- entiated cultural entities (Turq, 2000).

Meanwhile, the data from the main sites in the southeastern regions ofFrance, such as Payre, Bau de l'Aubesier, Baume Bonne, Lazaret or Caunede l’Aragó, demonstrate how the standardisation of technical behaviours and the development of long and elaborate operative chains seem to develop from 300 ka (Moncel, 1995; Gagnepain and Gaillard, 2005; Barsky, 2013; Hérisson et al., 2016; Carmignani et al., 2017). The most important knapping methods documented throughout MIS 9 and 6 last until the most recent periods of the Middle Palaeolithic, notably enriching the débitage of blades within Levallois operative chains from MIS 4 (Moncel, 2003). It is interesting to highlight how Levallois technology has been long represented in this region at Orgnac 3, where a greater de- velopment of this technique is documented from MIS 9 and 8 at the ex-pense of bifacial tooling that progressively descends (Moncel et al., 2005, 2012). This marks the emergence of Middle Palaeolithic behaviour from atechnical and subsistence perspective (Hérisson et al., 2016).

Regarding the Italian Peninsula, data from chronostratigraphic and technological studies are scarce for between 400 and $200 \mathrm{ka}$, and the information available is reduced and fragmented. Despite this, sites such as Torre in Pietra, Cave dall'Olio and Guado San Nicola provide important information for the reconstruction of this period. At the first site, the application of discoid and Levallois systems is documented in association with the production of bifaces (Piperno and Biddittu, 1978; Grimaldi, 1998). At the second, a wide variability is witnessed in the production schemes, among which the Levallois and laminar methods stand out (Fontana et al., 2013). At the third site, the appearance of theoldest Levallois technology in Italy dates to around MIS 11 and raises the possibility that the transition between the Lower and Middle Pa- laeolithic occurred in Italy and, more broadly in Europe, before what was previously considered by many authors, delaying it almost an en- tire glacial cycle (Picin et al., 2013; Peretto et al., 2016; Hérisson et al., 2016; Soriano and Villa, 2017).

Finally, in relation to the Iberian Peninsula, a clear coexistence is documented between Late Acheulean and Middle Palaeolithic sites whichseem to start around MIS 9. For example, in the northern region at sites such as Gran Dolina, acording to Ollé et al. (2016), the TD10.1 assemblage should be classified as a late Acheulean, with some transitional featurestending towards the Early Middle Paleolithic. It focuses mainly on cen- tripetal schemes and the presence of Levallois elements. Macro-tooling elements are rare and retouched flakes of the Mousterian type dominate(Ollé et al., 2013). In the central peninsular area, Cuesta de la Bajada and Ambrona stand out. At the first site, according to Santonja et al. (2014), the small size of the flakes, consistent with the size of the cores, is a fundamental feature of the industry of Cuesta de la Bajada and the in- dustry of level CB3, like that of the whole site, is characterized foremost by the absence of elements configured by façonnage. The branched-type productions and the recycling of flakes through the re-sharpening of tools and exhausted cores are worth noting (Santonja et al., 2014). At Ambrona, discoid knapping predominates, the bifacial component is reduced and the main tooling is made from flakes used as sidescrapers and denticulates (Santonja and Pérez-González, 2006). On the Mediterranean façade, Bo- lomor is an example of an industry without Acheulean influence in which branched productions dominate, few elements of the Levallois type are documented and obtaining small supports from exhaustive cores are im-portant (Fernández-Peris, 2007). Finally, in the southern region, we have, on one hand, the Cueva del Ángel and Solana del Zamborino sites char-acterised by an industry of flakes with an important bifacial component, and, on the other hand, Las Grajas where features related to branching processes are documented and the Acheulean macro-tools and Levallois elements are practically non-existent (Benito del Rey, 1982; Barroso-Ruiz et al., 2011; Jiménez et al., 2011).

In this context, the main objective of this work is to discuss the technological changes documented along the Cova Negra sequence whichcovers a time span that, based on the new dates obtained through ESR, begins with some basal industries at the end of the Middle Pleistocene and continues into the Upper Pleistocene. In this sense, the data provided byCova Negra provide the opportunity to examine the emergence of new technical strategies during a crucial period - the transition from the Lower to Middle Palaeolithic - and the development of the Middle Palaeolithic in the important geographical area of the Iberian Peninsula. 


\section{Materials and methods}

\subsection{Cova Negra}

The Cova Negra site is located on the left flank of the Albaida River, in the Valencian town of Xàtiva. It measures about $18 \mathrm{~m}$ long at the mouth of the cave and is $25 \mathrm{~m}$ depth, with an orientation to the east which makes it a good site for habitation, both in climatic and spatial terms (Fig. 1).

As an archaeological site, it is first mentioned by Vilanova i Piera in 1872 and by Cartailhac in 1886. The first excavation was carried out in the 1930s by Gonzalo Viñes, although information is sparse because hispremature death prevented the publication of his findings. In the 1950s, Francisco Jordá resumed work in the cavity, excavating a large part of the surface and stratigraphy of the cave in different sectors. However, the publications were limited to synthesis works that did not provide detail about the industrial characterisation of the site. This task was performed by Valentín Villaverde in the 1980s, who returned to field work in the cavity and studied the lithic materials for his $\mathrm{PhD}$ dis- sertation. His objectives were to obtain more information about the stratigraphy and chronology and place the site in the context of the European Middle Palaeolithic. Finally, from 2013 to 2017, a new team led by Villaverde and Aleix Eixea resumed the excavation work with the objective of determining the stratigraphy with greater precision and obtaining absolute dating for the different levels due to the erratic re- sults collected in previous years. In addition, new multidisciplinary studies (e.g. sedimentology, micromorphology, microfauna, phytoliths, etc.) were proposed in order to expand and update the existing in- formation.

Regarding the stratigraphic and sedimentary sequence, studies dateback to 1986 (Fumanal, 1986; Fumanal and Villaverde, 1997) when 36 levels were identified in several profiles of the site. Subsequently, they were unified in 15 levels grouped into 6 phases (Villaverde, 2009): A (XV), B (XIV and XIII), C (XII), D (XI-V), E (IV) and F (III-I). Towards

2013 the archaeological campaigns were restarted mainly in the West sector C2 in which the upper section of the sequence was recorded, levels I to V (Villaverde et al., 2014) (Fig. 2). In the lower section, comprising levels VI to $\mathrm{XV}$, was recorded in the South sector P-8/9 andSouth-east sector N-11 (Figs. 3 and 4). In this sense, the stratigraphic and sedimentary record is synthetically detailed in the following Tables 1 and 2.

New ESR/U-Th ages obtained for the archaeological sequence in- dicate a late Middle Pleistocene chronology, ranging from MIS 8 for levels XII and XI to MIS 6 for the levels V and III (Richard et al., 2019).

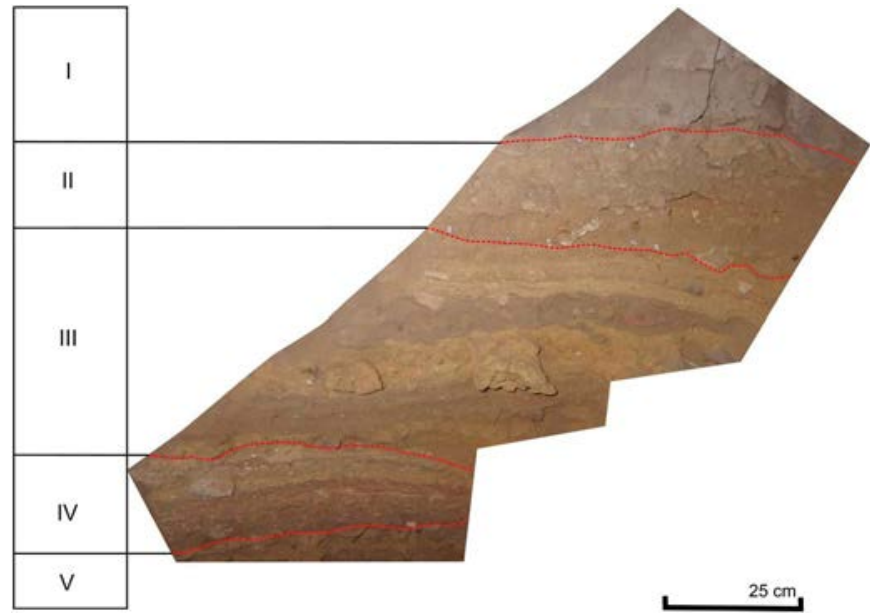

Fig. 2. C-2 profile from West sector indicating levels I to V.

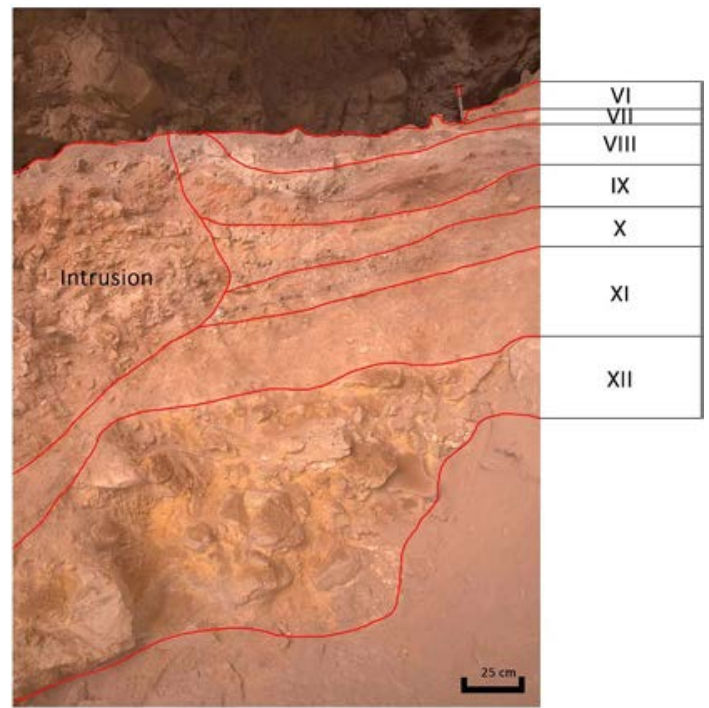

Fig. 3. P-9 profile from South sector indicating levels VI to XII.

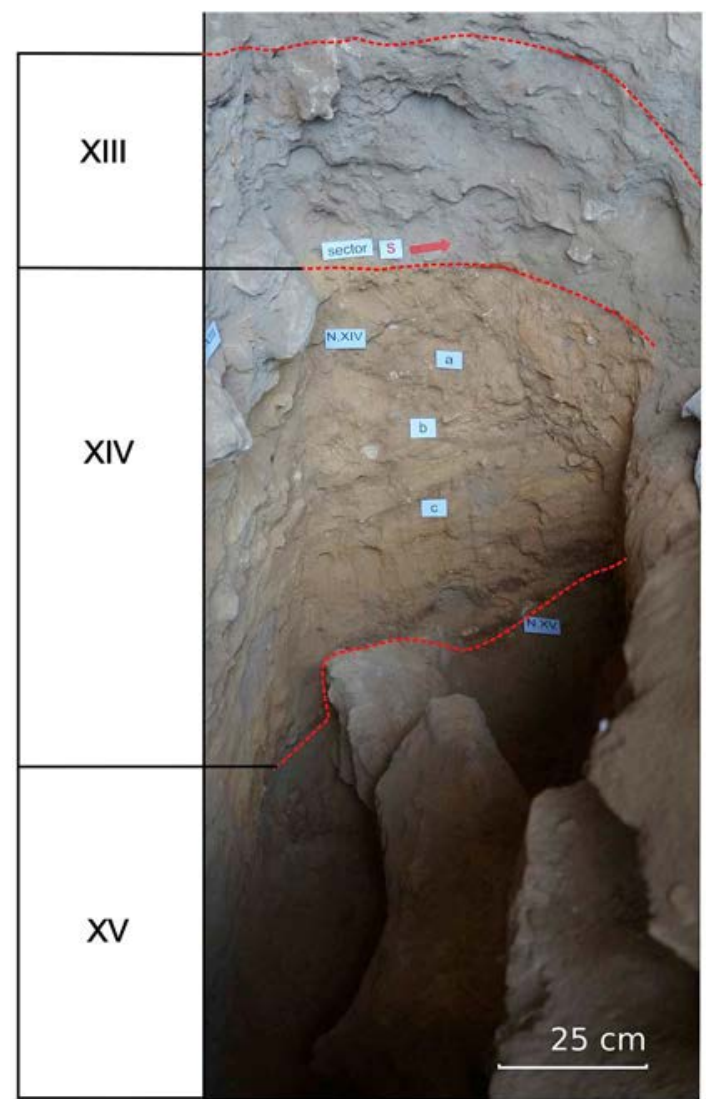

Fig. 4. N-11 profile from South-east sector indicating levels XIII to XV.

\subsection{Methods}

The proposal for the management of lithic materials and bone re- mains recovered in the excavation campaigns from 1950 to 1956 in Cova Negra (Villaverde, 1984) was based on the revision of the strati- graphic sequence made in 1981-1982 in the zone adjacent to sectors K- 2 and C. The sedimentological and geoarchaeological study carried out by María Pilar Fumanal made it possible to establish the initial 
Table 1

Synthesis of the stratigraphic and sedimentary field description from Cova Negra. South sector (the lithology is from dolomitic limestones).

\begin{tabular}{|c|c|c|c|c|c|c|c|}
\hline $\begin{array}{l}\text { Cova Negra } \\
\text { Profile/ } \\
\text { Levels }\end{array}$ & Thickness (cm) & Colour & Coarse fraction & Fine fraction & Boundaries & $\begin{array}{l}\text { Organic and inorganic } \\
\text { components }\end{array}$ & $\begin{array}{l}\text { Chronology (ka) } \\
\text { (ESR) }\end{array}$ \\
\hline $\begin{array}{c}\mathrm{P}-8 / \mathrm{VI} \\
\mathrm{A}\end{array}$ & 5 & 7,5YR4/4 & Some stones & Clayey silts with fine sands & Sharp & & \\
\hline B & 6 & 7,5YR6/ 4 & Some gravel & Silty sands & Sharp & & \\
\hline $\mathrm{P}-8 / \mathrm{VII}$ & 8 & 10YR5/3 & $\begin{array}{l}\text { Stones increase. Some } \\
\text { carbonated concretion }\end{array}$ & Silty sands & Sharp & & \\
\hline P-8/9-VIIIA & $2-14$ & 10YR6/3 & Some subangular stones & Silts & Sharp & $\begin{array}{l}\text { Carbonated ash } \\
\text { accumulation }\end{array}$ & \\
\hline B & $5-6$ & $\begin{array}{l}\text { 7,5YR6/3 P- } \\
8 \\
\text { 5YR5/6 P-9 }\end{array}$ & $\begin{array}{l}\text { Some stones with carbonated } \\
\text { concretions }\end{array}$ & Silty sands & Sharp & Rubified traces & \\
\hline $\mathrm{C}(\mathrm{P}-8)$ & $1-6$ & 10YR6/4 & & $\begin{array}{l}\text { Sandy silt, with concretionsin } \\
\text { the east area }\end{array}$ & Sharp & $\begin{array}{l}\text { Carbonated ash } \\
\text { accumulation }\end{array}$ & \\
\hline $\mathrm{D}$ & $1-5$ & $\begin{array}{l}7,5 Y R 4 / 6 \text { P- } \\
8 \\
7,5 Y R 6 / 6 \text { P- } \\
9\end{array}$ & Some gravels & Clayey silt with sands & Sharp & Organic material & \\
\hline P-9/IX & $5-8$ & 10YR6/6 & Gravels & Silty sands & Sharp & & \\
\hline $\mathrm{P}-9 / \mathrm{X}$ & 14 & $\begin{array}{c}\text { 7,5YR4/6 } \\
\text { 7,5YR6/6 } \\
\text { 7,5YR5/4 }\end{array}$ & Some gravels from 1 to $3 \mathrm{~cm}$ & Sandy silt laminations & Sharp & Microfaunal remains & \\
\hline $\mathrm{P}-9 / \mathrm{XI}$ & 20 & 10YR6/4 & Subrounded stones (5-10\%) & Silty sands & Sharp & & $261 \pm 42$ \\
\hline P-9/XII & $\begin{array}{l}\text { 50-55 (at least } \\
\text { until now) }\end{array}$ & 10YR7/6 & Blocks & Silty sands & Sharp & & $273 \pm 26$ \\
\hline N-11/XIII & 60 & 10YR6/6 & $\begin{array}{l}\text { Subangular blocks } \\
(30-40 \mathrm{~cm})\end{array}$ & Sands & & & \\
\hline $\begin{array}{c}\text { N-11/XIV } \\
\text { A }\end{array}$ & $13-17$ & 10YR6/6 & $\begin{array}{l}\text { Stones from } 1 \text { to } 3 \mathrm{~cm} \text { with } \\
\text { some alterations }\end{array}$ & Silty sands & Erosive contact & & \\
\hline B & 5 & 10YR7/6 & Stones and gravels & Sands & Sharp & & \\
\hline C & $35-40$ & 10YR4/4 & & $\begin{array}{l}\text { Clayey silt and sands } \\
\text { laminations (rhytmites?) }\end{array}$ & Sharp & & \\
\hline N11/XV & $\begin{array}{l}20 \text { (at least until } \\
\text { now) }\end{array}$ & $5 Y 9 / 1$ & & Marl & Sharp & & \\
\hline
\end{tabular}

chronology for various phases that later grew to include fifteen levels grouped into six phases (Fumanal and Villaverde, 2009). The problems with this proposed chronological division came from two fundamental circumstances. First, the inclination stratigraphy of the site had a marked NW-SE orientation, with significant lateral variations in the levels. The excavation system of the 1950s consisted of artificial hor- izontal layers of variable thickness (between 10 and $30 \mathrm{~cm}$, but some- times higher) in sectors of a certain surface (between 10 and $16 \mathrm{~m}^{2}$ ). Second, the reference profile to establish the thickness of the levels was located in an area (north-central) that presented variations with respectto the sedimentary record in the upper levels of the rest of the cavity. The proposed chronological divisions, adopted both in the afore- mentioned work

(Villaverde, 1984) and in the recent review of thelithic materials (Eixea, 2015) tried to include the largest number ofremains in the characterisation of the lithic industries recovered in thesite of the old excavations, i.e. those that have provided the greatestnumber of materials in the excavated

extension. The work carried out atCova Negra between 2016 and 2018, as well as the review of the

Table 2

Synthesis of the stratigraphic and sedimentary field description from Cova Negra. West sector (the lithology is from dolomitic limestones).

\begin{tabular}{|c|c|c|c|c|c|c|c|}
\hline $\begin{array}{l}\text { Cova Negra } \\
\text { Profile/ } \\
\text { Levels }\end{array}$ & Thickness (cm) & Colour & Coarse fraction & Fine fraction & Boundaries & $\begin{array}{l}\text { Organic and inorganic } \\
\text { components }\end{array}$ & Chronology (ka)(ESR) \\
\hline $\mathrm{C} 2 / \mathrm{I}$ & 20 & & Some stones $(6-10 \mathrm{~cm})$ & Clays & Sharp & & \\
\hline $\mathrm{C} 2 / \mathrm{II}$ & 25 & 10 YR $7 / 4$ & Gravels and stones $(7-10 \mathrm{~cm})$ & Silty sands & Sharp & & \\
\hline $\begin{array}{c}\mathrm{C} 2 / \mathrm{III} \\
\mathrm{A}\end{array}$ & 12 & 10YR6/6 & $\begin{array}{l}\text { Abundant stones and subrounded } \\
\text { gravels with some blocks }\end{array}$ & Silty sands & Sharp & $\begin{array}{l}\text { Charcoals and laminations. } \\
\text { Abundant microfaunal remains }\end{array}$ & $\begin{array}{l}206 \pm 21 \\
193 \pm 19\end{array}$ \\
\hline B & $2-5$ & 10 YR 6/4 & Subangular stones and gravels & Sandy silt & Sharp & Rubified traces & \\
\hline $\mathrm{C}$ & $8-10$ & 10YR7/8 & $\begin{array}{l}\text { Angular stones with concretions } \\
\text { and gravels }\end{array}$ & Silty sands & Sharp & & \\
\hline $\begin{array}{l}\mathrm{D} \\
\mathrm{C} 2 / \mathrm{IV}\end{array}$ & 14 & $10 Y R 7 / 4$ & Angular stones increase & Sandy silt & Sharp & Charcoals & \\
\hline A & 8 & 10YR5/6 & Subangular stones $(2-4 \mathrm{~cm})$ & $\begin{array}{l}\text { Clayey silt with sands and } \\
\text { carbonated nodules }\end{array}$ & Difusse & $\begin{array}{l}\text { Charcoals and microfaunal } \\
\text { remains }\end{array}$ & \\
\hline B & 14 & 10YR5/8 & $\begin{array}{l}\text { Subangular to angular stones(1- } \\
2 \mathrm{~cm})\end{array}$ & $\begin{array}{l}\text { Laminations of clayey silt with } \\
\text { some carbonated concretion }\end{array}$ & Sharp & Charcoals punctuations & \\
\hline $\mathrm{C} 2 / \mathrm{V}$ & 10 & $10 Y R 7 / 4$ & $\begin{array}{l}\text { Angular to subangular } \\
\text { stones }>5 \mathrm{~cm} \text { increase }\end{array}$ & Silty sands & Sharp & & $\begin{array}{l}146 \pm 34 \\
168 \pm 20\end{array}$ \\
\hline
\end{tabular}


Table 3

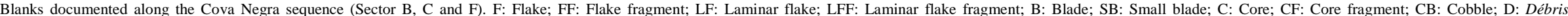

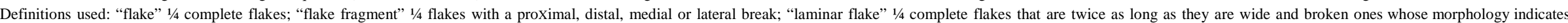
such were the original proportions. Flakes are defined regardless of size, based on the presence of technical attributes, morphology and perceived intentionality of the extraction, with no arbitrary cut-off at a given minimum size.

\begin{tabular}{|c|c|c|c|c|c|c|c|c|c|c|c|c|c|c|c|c|c|c|c|c|c|c|c|c|}
\hline & \multicolumn{24}{|c|}{ Sector B } \\
\hline & III & $\%$ & IV & $\%$ & $\mathrm{~V}$ & $\%$ & VI & $\%$ & VII & $\%$ & VIII & $\%$ & IX & $\%$ & $\mathrm{X}$ & $\%$ & $\mathrm{XI}$ & $\%$ & XII & $\%$ & XIII & $\%$ & XIV & $\%$ \\
\hline$F+F F$ & 60 & $92,3 \%$ & 33 & $100,0 \%$ & 62 & $89,9 \%$ & 22 & $91,7 \%$ & 17 & $100,0 \%$ & - & - & - & - & - & - & 9 & $81,8 \%$ & 15 & $88,2 \%$ & 57 & $95,0 \%$ & 77 & $96,3 \%$ \\
\hline $\mathrm{LF}+\mathrm{LFF}$ & 1 & $1,5 \%$ & - & - & - & - & - & - & - & - & - & - & - & - & - & - & - & - & - & - & - & - & - & \\
\hline $\mathrm{B}+\mathrm{SB}$ & 1 & $1,5 \%$ & - & - & 1 & $1,4 \%$ & 1 & $4,2 \%$ & - & - & - & - & - & - & - & - & 1 & $9,1 \%$ & - & - & - & - & - & - \\
\hline $\mathrm{C}+\mathrm{CF}$ & 1 & $1,5 \%$ & - & - & 1 & $1,4 \%$ & 1 & $4,2 \%$ & - & - & - & - & - & - & - & - & - & - & - & - & 2 & $3,3 \%$ & - & \\
\hline $\mathrm{CB}$ & - & - & - & - & - & - & - & - & - & - & - & - & - & - & - & - & - & - & - & - & - & - & 2 & 2,35\% \\
\hline D & 2 & $3,1 \%$ & - & - & 5 & $7,2 \%$ & - & - & - & - & - & - & - & - & - & - & 1 & $9,1 \%$ & 2 & $11,8 \%$ & 1 & $1,7 \%$ & 1 & \\
\hline Total & 65 & $100,0 \%$ & 33 & $100,0 \%$ & 69 & $100,0 \%$ & 24 & $100,0 \%$ & 17 & $100,0 \%$ & - & - & - & - & - & - & 11 & $100,0 \%$ & 17 & $100,0 \%$ & 60 & $100,0 \%$ & 80 & $100,0 \%$ \\
\hline
\end{tabular}

\begin{tabular}{|c|c|c|c|c|c|c|c|c|c|c|c|c|c|c|c|c|c|c|c|c|c|c|c|c|}
\hline & \multicolumn{24}{|c|}{ Sector C } \\
\hline & III & $\%$ & IV & $\%$ & $\mathbf{v}$ & $\%$ & VI & $\%$ & VII & $\%$ & VIII & $\%$ & IX & $\%$ & $\mathbf{x}$ & $\%$ & XI & $\%$ & XII & $\%$ & XIII & $\%$ & XIV & $\%$ \\
\hline$F+F F$ & 79 & $81,4 \%$ & 32 & $80,0 \%$ & 20 & $64,5 \%$ & - & - & - & - & 11 & $100,0 \%$ & 9 & $100,0 \%$ & 2 & $100,0 \%$ & 24 & $100,0 \%$ & 48 & $98,0 \%$ & 68 & $100,0 \%$ & 14 & $93,3 \%$ \\
\hline $\mathrm{LF}+\mathrm{LFF}$ & - & - & - & - & 1 & $3,2 \%$ & - & - & - & - & - & - & - & - & - & - & - & - & - & - & - & - & - & \\
\hline $\mathrm{B}+\mathrm{SB}$ & 4 & $4,1 \%$ & - & - & - & - & - & - & - & - & - & - & - & - & - & - & - & - & - & - & - & - & 1 & $6,7 \%$ \\
\hline $\mathrm{C}+\mathrm{CF}$ & 6 & $6,2 \%$ & - & - & - & - & - & - & - & - & - & - & - & - & - & - & - & - & - & - & - & - & - & \\
\hline СВ & 1 & $1,0 \%$ & - & - & - & - & - & - & - & - & - & - & - & - & - & - & - & - & 1 & $2,0 \%$ & - & - & - & $=$ \\
\hline $\mathrm{D}$ & 7 & $7,2 \%$ & 8 & $20,0 \%$ & 10 & $32,3 \%$ & - & - & - & - & - & - & - & - & - & - & - & - & - & - & - & - & - & \\
\hline Total & 97 & $100,0 \%$ & 40 & $100,0 \%$ & 31 & $100,0 \%$ & - & - & - & - & 11 & $100,0 \%$ & 9 & $100,0 \%$ & 2 & $100,0 \%$ & 24 & $100,0 \%$ & 49 & $100,0 \%$ & 68 & $100,0 \%$ & 15 & $100,0 \%$ \\
\hline
\end{tabular}

\begin{tabular}{|c|c|c|c|c|c|c|c|c|c|c|c|c|c|c|c|c|c|c|c|c|c|c|}
\hline & \multicolumn{22}{|c|}{ Sector $F$} \\
\hline & I & $\%$ & II & $\%$ & III & $\%$ & IV & $\%$ & $\mathbf{v}$ & $\%$ & VI & $\%$ & VII & $\%$ & VIII & $\%$ & $\mathbf{I X}$ & $\%$ & $\mathbf{x}$ & $\%$ & XI & $\%$ \\
\hline $\mathbb{E}_{F}$ & 26 & $74,3 \%$ & 13 & $76,5 \%$ & 17 & $\underline{77,3 \%}$ & $\underline{3}$ & $30,0 \%$ & 14 & $73,7 \%$ & $\underline{9}$ & $90,0 \%$ & 15 & $\underline{71,4} \%$ & $\underline{8}$ & $80,0 \%$ & $\underline{8}$ & $100,0 \%$ & $=$ & $=$ & 13 & $100,0 \%$ \\
\hline$B+S B$ & - & - & - & - & - & - & - & - & - & - & - & - & - & - & - & - & - & - & - & - & - & - \\
\hline $\mathrm{C}+\mathrm{CF}$ & - & - & - & - & 2 & $9,1 \%$ & - & - & 3 & $15,8 \%$ & - & - & 1 & $4,8 \%$ & - & - & - & - & - & - & - & - \\
\hline $\mathrm{CB}$ & - & - & - & - & - & - & 1 & $10,0 \%$ & 1 & $5,3 \%$ & - & - & - & - & - & - & - & - & - & - & - & - \\
\hline D & 9 & $25,7 \%$ & 4 & $23,5 \%$ & 3 & $13,6 \%$ & 6 & $60,0 \%$ & 1 & $5,3 \%$ & 1 & $10,0 \%$ & 5 & $23,8 \%$ & 2 & $20,0 \%$ & - & - & - & - & - & - \\
\hline Total & 35 & $100,0 \%$ & 17 & $100,0 \%$ & 22 & $100,0 \%$ & 10 & $100,0 \%$ & 19 & $100,0 \%$ & 10 & $100,0 \%$ & 21 & $100,0 \%$ & 10 & $100,0 \%$ & 8 & $100,0 \%$ & - & - & 13 & $100,0 \%$ \\
\hline
\end{tabular}


Table 4

Lithic densities per $\mathrm{m}^{3}$ and number of remains documented in the differentlevels along the Cova Negra sequence (Sector B, C and F).

\begin{tabular}{|c|c|c|c|c|c|}
\hline \multicolumn{2}{|c|}{ Sector B } & \multicolumn{2}{|c|}{ Sector C } & \multicolumn{2}{|c|}{ Sector F } \\
\hline $\begin{array}{l}\text { Number } \\
\text { of } \\
\text { remains }\end{array}$ & Density/m3 & $\begin{array}{l}\text { Number } \\
\text { of } \\
\text { remains }\end{array}$ & Density/m3 & $\begin{array}{c}\text { Number } \\
\text { of } \\
\text { remains }\end{array}$ & Density/m3 \\
\hline
\end{tabular}

\begin{tabular}{ccccccc}
\hline I & - & - & - & - & 35 & 10.8 \\
II & - & - & - & - & 17 & 7.1 \\
III & 65 & 21.7 & 97 & 10.1 & 22 & 6.1 \\
IV & 33 & 6.6 & 40 & 5 & 10 & 4.2 \\
V & 69 & 17.3 & 31 & 9.7 & 19 & 4.8 \\
VI & 24 & 12 & - & - & 10 & 1.9 \\
VII & 17 & 8.5 & - & - & 21 & 7.6 \\
VIII & - & - & 11 & 1.5 & 10 & 4.2 \\
IX & - & - & 9 & 0.9 & 8 & 2.7 \\
X & - & - & 2 & 0.4 & - & - \\
XI & 11 & 1.2 & 24 & 1.4 & 13 & 24 \\
XII & 17 & 5.7 & 49 & 5.1 & - & - \\
XIII & 60 & 3.5 & 68 & 2.2 & - & - \\
XIV & 80 & 5 & 15 & 0.6 & - & - \\
\hline
\end{tabular}

stratigraphic sequence carried out after the end of the excavations ofthe 1980s and 1990s, allow the filling characteristics of the cavity in theWest and

South sectors to be defined more precisely. This updatedstratigraphic vision, with the determination of different thickness levelsand their respective profiles, and the outstanding slopes detected in thesite of available stratigraphic profiles, has led to a correlation review ofthe levels excavated during the 1950s with the currently establishedsequence, with the idea of specifying the maximum sequential positionof the archaeological material and possibly correcting previous errors. The chosen procedure has been to compare the depths reached inthe different levels of sectors B, C and F with the depths of the levels inthe reference profiles of the West and South sectors, which are im-mediately adjacent to these three sectors. It is clear that the procedurestill implies a certain imprecision since the artificial layers of the ex-cavation campaigns of the 1950s did not adjust to the stratigraphy orthe slope of the levels. However, when dealing with the three sectorsmentioned separately, and considering the preserved thickness of the

profiles, this imprecision is reduced to a minimum.

It should be noted that it is possible that there may be some intru- sion phenomenon in sector $\mathrm{B}$ as a result of a channel detected in the left sagittal section of this sector during the 2016-2018 excavations. In the distal part of the latter area, a sedimentary scar is produced by a channel that cuts levels $\mathrm{V}$ through VI-XII and was subsequently filled with sediments after levels IV-III. The process seems to be in relation tothe gallery that is located in that area of the cavity, characterised by a high downward slope, which has been able to favour processes in that direction. The excavation of this sector in the last excavation campaignshas confirmed the growth of the scrambled level in that area and the direction of the erosive channel in that direction. Given the impossibility of determining the channel origin and its morphology in relation to sector B (excavated in 1950), the possibility of intrusive materials from the upper levels cannot be ruled out, as has been ob- served in the South sector. We will return to this aspect when com- menting on the materials of sector B.

By opting for this procedure, we have refrained from including some sectors from the 1950s' excavations in the proposed chronology. This is the case in sectors $\mathrm{D}$ and $\mathrm{E}$ because there are no immediate visible re-ference profiles that cover the entire filling sequence and therefore it is not possible to correct the possible correlation of the artificial layers of excavation with the currently determined levels. This also occurred in sectors $\mathrm{G}, \mathrm{H}, \mathrm{J} 1, \mathrm{~J} 2$ and $\mathrm{K} 2$ because the stratigraphy in the available profiles does not cover the entire sequence. In addition the profiles have a substantial variations with respect to the rest of the surface that make an adjusted correlation unfeasible with the sequence established in the remaining sectors.

Lithic assemblage is studied from a technological and typological point of view. On the one hand, according to the so-called chaîne opératoire approach (Lemonnier, 1986; Karlin et al., 1991) with the aim

of recognising various stages in lithic tool making and investigating thebasic conceptual processes that underlay the sequence of manu- facturing steps in stone tool production. Accordingly, we regard the production of stone artefacts as a dynamic process, from the acquisition of raw material to the discard of used tools. It thus aims at re-estab- lishing the lifecycle of the stone tools. In this process, there are four main components: raw material acquisition, production, utilisation, and discard (Boëda et al., 1990; Julien, 1992; Tixier et al., 1980; Texier, 1996). And, on the other hand, typological classification (includingthose with macro-use wear) were classified using the Bordes' typelist (1988).

\section{Results}

\subsection{Sector $B$}

\subsubsection{Stratigraphy}

Sector B uses the right sagittal of the South sector as a reference profile, which coincides with its right sagittal profile. Sector B has been tentatively ordered from level III and with greater certainty from $\mathrm{V}$ to the base, level XIV. Levels I and II have been affected in that area by a pre-modern removal process if we exempt the first centimetre of the deposit (Villaverde and Eixea, 2017), which prevents differentiating between the two. The decrease of the alteration towards the centralarea of the cavity has allowed us to locate the depths reached in the excavation of this sector for layers 4-5, which would correspond to levels III and IV. In total, 376 remains are unevenly distributed across their assigned levels.

\subsubsection{Lithics}

A greater number of remains are observed at base levels (XIII-XIV) and at levels $\mathrm{V}$ and III (Tables 3 and 4). In each of these levels, the number of lithic remains reaches or exceeds 60 elements. The re- maining levels show a marked decrease, which is characterised in levels VIII to X by a total absence of material. This situation does not occur inthe other two sectors studied, nor was it observed in the groupingcarried out in the 1984 work. At these levels, the number of remains was below 200, but was greater than the quantities accounted for at levels XI-XIV.

The importance of these variations is due to the interest in de-termining the characteristics of the occupations in Cova Negra. This is in part already defined from the excavation of the West sector as a zonaloccupation with low intensity, probably as a result of the small number of occupants and sporadic stays in the cavity (Villaverde et al., 1996, 2009). When the area to which the archaeological remains refer to is reduced, these types of zonal variations are more easily observed and reveal changing areas of occupation along the sequence.

When assessing the density of lithic remains per cubic metre, it is observed that level III reaches the highest volume of remains, followed by level V and, to a lesser extent, level VI. Its depths are markedly lower than those from the basal levels, so it seems that the occupation events were either more continuous or had greater intensity or duration. In general, it may be noted that in this sector the densities of the basal levels (XI-XIV) are notably lower than those of levels II to VII. This is afeature repeated in the other two sectors reviewed in this work. 
Table 5

Reduction strategies documented along the Cova Negra sequence (Sector B, C and F).

\begin{tabular}{|c|c|c|c|c|c|c|c|c|c|c|c|c|c|c|c|c|c|c|c|c|c|c|c|c|}
\hline & \multicolumn{24}{|c|}{ Sector B } \\
\hline & III & $\%$ & IV & $\%$ & $\mathrm{~V}$ & $\%$ & $\mathrm{VI}$ & $\%$ & VII & $\%$ & VIII & $\%$ & IX & $\%$ & $\mathrm{x}$ & $\%$ & XI & $\%$ & XII & $\%$ & XIII & $\%$ & XIV & $\%$ \\
\hline Discoid & 23 & $35,4 \%$ & 16 & $48,5 \%$ & 30 & $43,5 \%$ & 10 & $41,7 \%$ & 8 & $47,1 \%$ & - & - & - & - & - & - & 7 & $63,6 \%$ & 6 & $35,3 \%$ & 26 & $43,3 \%$ & 41 & $51,3 \%$ \\
\hline Levallois & 29 & $44,6 \%$ & 10 & $30,3 \%$ & 22 & $31,9 \%$ & 9 & $37,5 \%$ & 3 & $17,6 \%$ & - & - & - & - & - & - & 1 & $9,1 \%$ & 5 & $29,4 \%$ & 15 & $25,0 \%$ & 17 & $21,3 \%$ \\
\hline Preferential & 14 & $21,5 \%$ & 4 & $12,1 \%$ & 4 & $5,8 \%$ & 6 & $25,0 \%$ & 2 & $11,8 \%$ & - & - & - & - & - & - & - & - & - & - & 7 & $11,7 \%$ & 5 & $6,3 \%$ \\
\hline Recurrent centripetal & 14 & $21,5 \%$ & 6 & $18,2 \%$ & 18 & $26,1 \%$ & 3 & $12,5 \%$ & 1 & $5,9 \%$ & - & - & - & - & - & - & 1 & $9,1 \%$ & 5 & $29,4 \%$ & 8 & $13,3 \%$ & 12 & $15,0 \%$ \\
\hline Recurrent unidirectional & 1 & $1,5 \%$ & - & - & - & - & - & - & - & - & - & - & - & - & - & - & - & - & - & - & - & - & 1 & $1,3 \%$ \\
\hline Quina & - & - & - & - & - & - & - & - & 1 & $5,9 \%$ & - & - & - & - & - & - & - & - & 1 & $5,9 \%$ & 4 & $6,7 \%$ & 5 & $6,3 \%$ \\
\hline Kombewa & - & - & 1 & $3,0 \%$ & 2 & $2,9 \%$ & 1 & $4,2 \%$ & 1 & $5,9 \%$ & - & - & - & - & - & - & 1 & $9,1 \%$ & - & - & 2 & $3,3 \%$ & 2 & $2,5 \%$ \\
\hline Indeterminate & 13 & $20,0 \%$ & 6 & $18,2 \%$ & 15 & $21,7 \%$ & 4 & $16,7 \%$ & 4 & $23,5 \%$ & - & - & - & - & - & - & 2 & $18,2 \%$ & 5 & $29,4 \%$ & 13 & $21,7 \%$ & 14 & $17,5 \%$ \\
\hline Total & 65 & $100,0 \%$ & 33 & $100,0 \%$ & 69 & $100,0 \%$ & 24 & $100,0 \%$ & 17 & $100,0 \%$ & - & - & - & - & - & - & 11 & $100,0 \%$ & 17 & $100,0 \%$ & 60 & $100,0 \%$ & 80 & $100,0 \%$ \\
\hline
\end{tabular}

\begin{tabular}{|c|c|c|c|c|c|c|c|c|c|c|c|c|c|c|c|c|c|c|c|c|c|c|c|c|}
\hline & \multicolumn{24}{|c|}{ Sector $\mathbf{C}$} \\
\hline & III & $\%$ & IV & $\%$ & $\mathbf{v}$ & $\%$ & VI & $\%$ & VII & $\%$ & VIII & $\%$ & IX & $\%$ & $\mathbf{x}$ & $\%$ & XI & $\%$ & XII & $\%$ & XIII & $\%$ & XIV & $\%$ \\
\hline Discoid & 44 & $45,4 \%$ & 12 & $30,0 \%$ & 18 & $58,1 \%$ & - & - & - & - & 10 & $90,9 \%$ & 7 & $77,8 \%$ & 2 & $100,0 \%$ & 18 & $75,0 \%$ & 33 & $67,3 \%$ & 47 & $69,1 \%$ & 12 & $80,0 \%$ \\
\hline Levallois & 25 & $25,8 \%$ & 10 & $25,0 \%$ & 2 & $6,5 \%$ & - & - & - & - & - & - & 1 & $11,1 \%$ & - & - & 3 & $12,5 \%$ & 9 & $18,4 \%$ & 17 & $25,0 \%$ & 3 & $20,0 \%$ \\
\hline Preferential & 9 & $9,3 \%$ & 7 & $17,5 \%$ & - & - & - & - & - & - & - & - & 1 & $11,1 \%$ & - & - & 3 & $12,5 \%$ & 2 & $4,1 \%$ & 4 & $5,9 \%$ & - & - \\
\hline Recurrent centripetal & 16 & $16,5 \%$ & 3 & $7,5 \%$ & 2 & $6,5 \%$ & - & - & - & - & - & - & - & - & - & - & - & - & 7 & $14,3 \%$ & 12 & $17,6 \%$ & 3 & $20,0 \%$ \\
\hline Recurrent unidirectional & - & - & - & - & - & - & - & - & - & - & - & - & - & - & - & - & - & - & - & - & 1 & $1,5 \%$ & - & - \\
\hline Kombewa & - & - & - & - & - & - & - & - & - & - & - & - & 1 & $11,1 \%$ & - & - & 1 & $4,2 \%$ & 1 & $2,0 \%$ & - & - & - & - \\
\hline Indeterminate & 28 & $28,9 \%$ & 18 & $45,0 \%$ & 11 & $35,5 \%$ & - & - & - & - & 1 & $9,1 \%$ & - & - & - & - & 3 & $12,5 \%$ & 6 & $12,2 \%$ & 4 & $5,9 \%$ & - & - \\
\hline \multirow[t]{3}{*}{ Total } & 97 & $100,0 \%$ & 40 & $100,0 \%$ & 31 & $100,0 \%$ & - & - & - & - & 11 & $100,0 \%$ & 9 & $100,0 \%$ & 2 & $100,0 \%$ & 24 & $100,0 \%$ & 49 & $100,0 \%$ & 68 & $100,0 \%$ & 15 & $100,0 \%$ \\
\hline & \multicolumn{24}{|c|}{ Sector $F$} \\
\hline & I & $\%$ & II & $\%$ & III & $\%$ & IV & $\%$ & $\mathbf{v}$ & $\%$ & VI & $\%$ & VII & $\%$ & VIII & I $\%$ & IX & $\%$ & $\mathbf{x}$ & $\%$ & $\mathbf{X I}$ & $\%$ & & \\
\hline Discoid & 11 & $31,4 \%$ & 2 & $11,8 \%$ & 9 & $40,9 \%$ & - & - & 8 & $42,1 \%$ & 8 & $80,0 \%$ & 10 & $47,6 \%$ & 5 & $50,0 \%$ & 6 & $75,0 \%$ & - & - & 4 & $30,8 \%$ & & \\
\hline Levallois & 8 & $22,9 \%$ & 5 & $29,4 \%$ & 6 & $27,3 \%$ & 2 & $20,0 \%$ & - & - & - & - & 3 & $14,3 \%$ & 3 & $30,0 \%$ & - & - & - & - & 3 & $23,1 \%$ & & \\
\hline Preferential & 1 & $2,9 \%$ & 1 & $5,9 \%$ & 1 & $4,5 \%$ & - & - & - & - & - & - & - & - & - & - & - & - & - & - & - & - & & \\
\hline Recurrent centripetal & 7 & $20,0 \%$ & 4 & $23,5 \%$ & 5 & $22,7 \%$ & 2 & $20,0 \%$ & - $\quad-$ & & - $\quad-$ & 3 & & $14,3 \%$ & & $30,0 \%$ & - & - & - & 3 & & $3,1 \%$ & & \\
\hline Quina & - & - & 1 & $5,9 \%$ & - & - & - & - & - & - & 1 & $10,0 \%$ & - & - & - & - & 1 & $12,5 \%$ & - & - & - & - & & \\
\hline Kombewa & 1 & $2,9 \%$ & 1 & $5,9 \%$ & - & - & - & - & 2 & $10,5 \%$ & - & - & - & - & - & - & - & - & - & - & - & - & & \\
\hline Indeterminate & 15 & $42,9 \%$ & 8 & $47,1 \%$ & 7 & $31,8 \%$ & 8 & $80,0 \%$ & 9 & $47,4 \%$ & 1 & $10,0 \%$ & 5 & $23,8 \%$ & 2 & $20,0 \%$ & 1 & $12,5 \%$ & - & - & 6 & $46,2 \%$ & & \\
\hline Total & 35 & $100,0 \%$ & 17 & $100,0 \%$ & 22 & $100,0 \%$ & 10 & $100,0 \%$ & 19 & $100,0 \%$ & 10 & $100,0 \%$ & 21 & $100,0 \%$ & 10 & $100,0 \%$ & 8 & $100,0 \%$ & - & - & 13 & $100,0 \%$ & & \\
\hline
\end{tabular}


Table 6

Main tool groups documented along the Cova Negra sequence (Sector B, C and F).

Sector B

\begin{tabular}{|c|c|c|c|c|c|c|c|c|c|c|c|c|}
\hline & & & & & & & & & & & & \\
\hline & III & IV & $\mathrm{V}$ & $\mathrm{VI}$ & VII & VIII & IX & $\mathrm{X}$ & XI & XII & XIII & XIV \\
\hline Points & - & - & - & - & - & - & - & - & - & - & - & - \\
\hline Levallois & 1 & 1 & - & 1 & 1 & - & - & - & - & - & - & 1 \\
\hline Mousterian & 1 & - & 1 & - & - & - & - & - & - & - & 1 & 1 \\
\hline Sidescrapers & 17 & 10 & 18 & 5 & 4 & - & - & - & 5 & 3 & 21 & 24 \\
\hline Simple & 10 & 4 & 5 & 2 & 2 & - & - & - & 2 & 2 & 9 & 12 \\
\hline Double & - & 2 & 3 & - & 1 & - & - & - & - & - & 3 & 1 \\
\hline Déjeté & 1 & - & - & - & - & - & - & - & 2 & - & 1 & 2 \\
\hline Convergent & 1 & 3 & - & - & - & - & - & - & - & - & 1 & 3 \\
\hline Transversal & 4 & 1 & 9 & 1 & 1 & - & - & - & 1 & 1 & 3 & 5 \\
\hline Thinned back & - & - & - & 1 & - & - & - & - & - & - & - & - \\
\hline Bifacial & - & - & - & - & - & - & - & - & - & - & - & - \\
\hline Other & 1 & - & 1 & 1 & - & - & - & - & - & - & 4 & - \\
\hline Notches and denticulates & 3 & 3 & 3 & 2 & 2 & - & - & - & 1 & - & 9 & 5 \\
\hline Upper Paleolithic group & 4 & 1 & 4 & - & 1 & - & - & - & 1 & 1 & 3 & 7 \\
\hline Bifaces & - & - & - & - & - & - & - & - & - & - & - & 3 \\
\hline Chopper & - & - & - & - & - & - & - & - & - & - & - & - \\
\hline Tayac point & - & - & - & - & - & - & - & - & - & - & - & 1 \\
\hline Limace & - & - & - & - & - & - & - & - & - & - & - & 1 \\
\hline Pieces with use-wear & 4 & - & 4 & 3 & - & - & - & - & - & 3 & 5 & 6 \\
\hline Other & 1 & 2 & - & - & 1 & - & - & - & - & 2 & 2 & 1 \\
\hline Total & 31 & 17 & 30 & 11 & 9 & - & - & - & 7 & 9 & 41 & 49 \\
\hline
\end{tabular}

Sector C

\begin{tabular}{|c|c|c|c|c|c|c|c|c|c|c|c|c|}
\hline & III & IV & $\mathbf{v}$ & VI & VII & VIII & IX & $\mathbf{x}$ & XI & XII & XIII & XIV \\
\hline Points & - & - & - & - & - & - & - & - & - & - & - & - \\
\hline Levallois & - & - & - & - & - & - & - & - & 1 & 1 & - & - \\
\hline Mousterian & 1 & - & - & - & - & - & - & - & - & 1 & - & 2 \\
\hline Sidescrapers & 20 & 3 & 11 & & & 9 & 4 & - & 9 & 23 & 32 & 9 \\
\hline Simple & 11 & 2 & 5 & - & - & 6 & 4 & - & 4 & 12 & 13 & 2 \\
\hline Double & 3 & - & 1 & - & - & - & - & - & - & 1 & 2 & 1 \\
\hline Déjeté & 1 & - & - & - & - & - & - & - & 2 & 1 & 7 & 1 \\
\hline Convergent & 1 & - & - & - & - & - & - & - & - & 1 & 1 & 1 \\
\hline Transversal & 4 & - & 3 & - & - & 1 & - & - & 2 & 4 & 4 & 2 \\
\hline Thinned back & - & - & - & - & - & - & - & - & - & 1 & 2 & - \\
\hline Bifacial & - & 1 & - & - & - & - & - & - & 1 & - & - & - \\
\hline Other & - & - & 2 & - & - & 2 & - & - & - & 3 & 3 & 2 \\
\hline Notches and denticulates & 5 & 4 & - & - & - & - & - & 1 & 7 & 5 & 14 & 1 \\
\hline Upper Paleolithic group & 2 & 3 & - & - & - & 1 & 2 & - & 3 & 4 & 2 & 1 \\
\hline Bifaces & - & - & - & - & - & - & - & - & 1 & 1 & - & - \\
\hline Chopper & - & - & - & - & - & - & - & - & - & - & - & - \\
\hline Tayac point & 6 & - & - & - & - & - & - & - & 1 & - & - & 1 \\
\hline Limace & - & - & - & - & - & - & - & - & - & - & - & 1 \\
\hline Pieces with use-wear & - & 1 & - & - & - & - & 2 & - & 1 & 1 & 2 & - \\
\hline Other & - & - & 2 & - & - & 1 & 1 & 1 & 1 & 1 & 7 & 1 \\
\hline Total & 34 & 11 & 13 & - & - & 11 & 9 & 2 & 24 & 37 & 57 & 16 \\
\hline
\end{tabular}

Sector $\mathbf{F}$

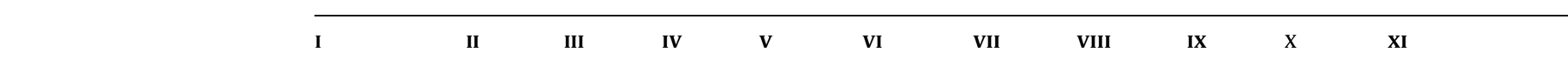

Points

Levallois

Mousterian

Sidescrapers

Simple

Double

Déjeté

Convergent

Transversal

Thinned back

Bifacial

Other

Notches and denticulates

Upper Paleolithic group

Bifaces

Chopper

Tayac point

Limace 


\begin{tabular}{|c|c|c|c|c|c|c|c|c|c|c|c|c|}
\hline & \multicolumn{12}{|c|}{ Sector B } \\
\hline & III & IV & $\mathrm{V}$ & VI & VII & VIII & IX & $\mathrm{X}$ & $\mathrm{XI}$ & XII & XIII & XIV \\
\hline Pieces with use-wear & 3 & 2 & 1 & 1 & 1 & 1 & - & - & - & - & 1 & \\
\hline Other & 1 & - & - & - & - & - & - & - & 1 & - & - & \\
\hline Total & 8 & 3 & 11 & 3 & 9 & 7 & 7 & 2 & 4 & - & 8 & \\
\hline
\end{tabular}

3.1.2.1. Technology. It is clear that discoid knapping and the technological and typological Quina elements predominate at levels XII-XIV and VII. In levels XII-XIV this situation coexists with the presence of the Levallois method, especially in levels XIII and XIV. This is similar to observations at other regional sites, but it is not possible toestablish whether the alternation of occupational patterns is associatedwith different knapping methods (Tables 5 and 6).

In relation to levels III-V, which are those at the base of the se- quence that provide the greatest number of remains, the evidence of the discoid strategy now coincides with the Levallois method, with very similar quantities, and Quina features disappear (Fig. 5).

In all cases, the raw materials are semi-local, with catchment areas 20-25 $\mathrm{km}$ from the site. The high percentage of transformation by retouching, the scant presence of chips and the reduced number of cores and products for their sharpening and maintenance, point to frag-mented operative chains, mainly limited to flakes and retouched ele- ments of a certain size, with very little variation in the blank sizes.

3.1.2.2. Typology. The small number of remains prevents excessive detail in the valuation of the different levels. It is interesting to associate the denticulates with discoid and Quina strategies, both in the upper and lower levels, and the strong typological homogeneity, dominated by simple lateral and transversal sidescrapers over those with two or more than two retouched edges (convergent, double and déjeté). Likewise, the presence of two bifaces and a Tayac point and a limace in level XIV is relevant (Figs. 6 and 7).

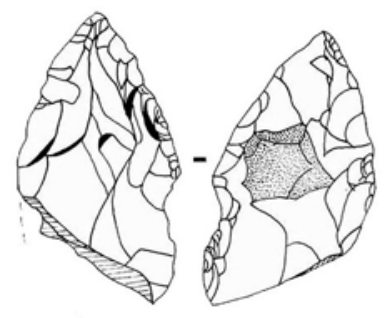

1

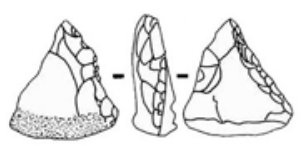

6

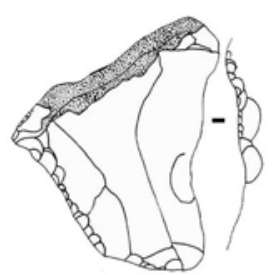

12

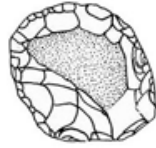

7

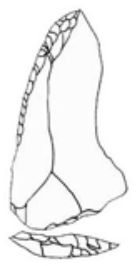

13

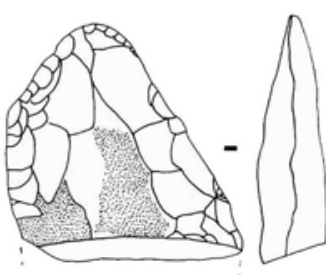

2

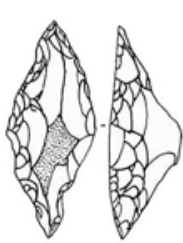

3

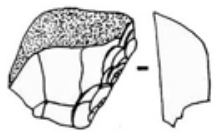

8

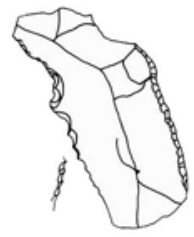

9

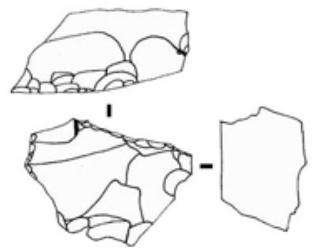

4

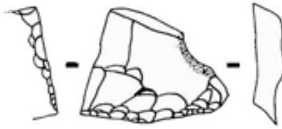

10

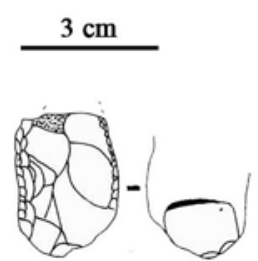

5

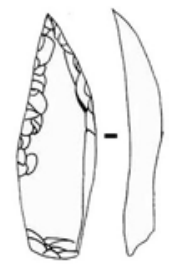

11

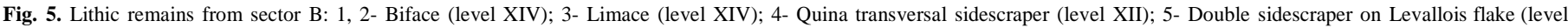

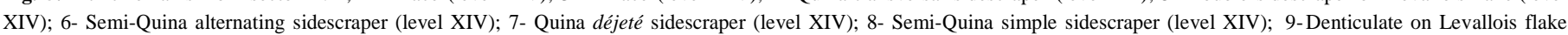

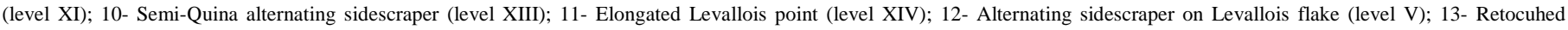

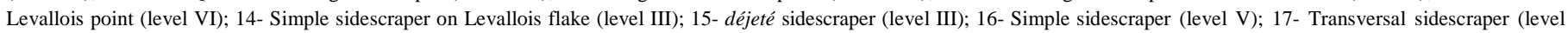
V); 18- Transversal sidescraper (capa III). 

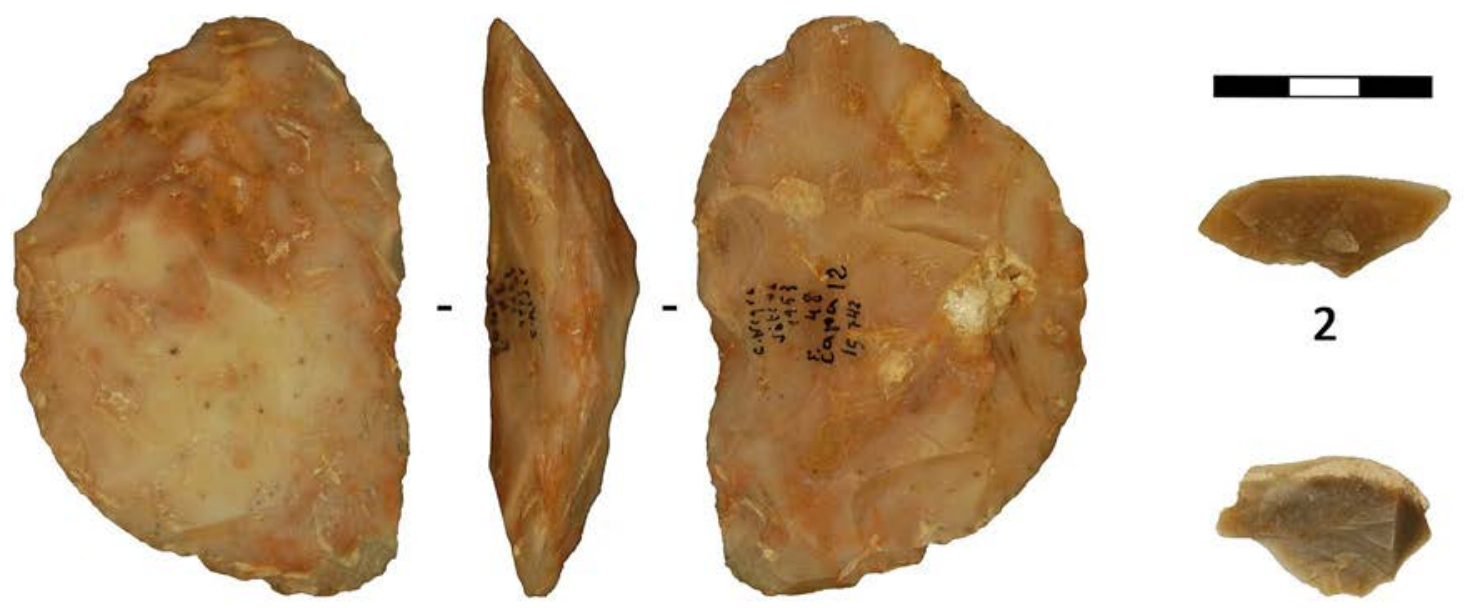

2

1

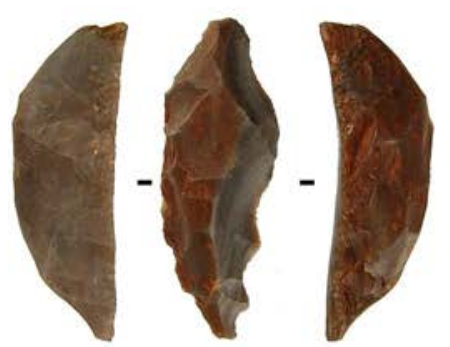

4
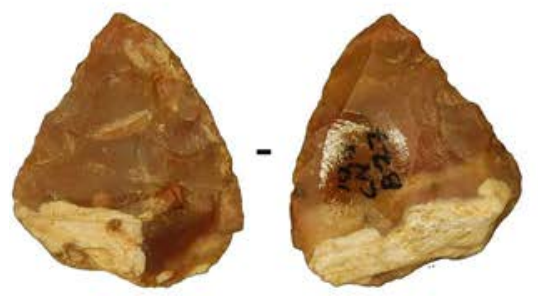

7
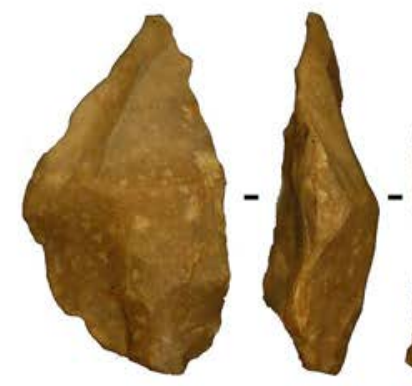

5
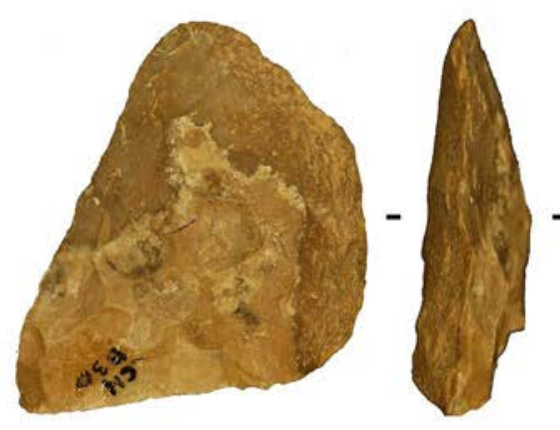

8

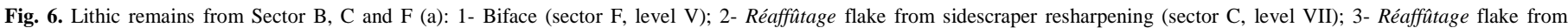

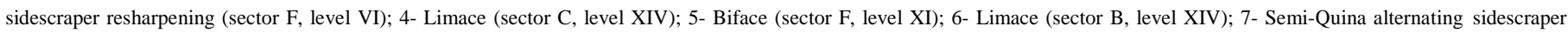
(sector B, level XIV); 8- Biface (sector B, level XIV).

The presence of a retouched Levallois point with laminar propor- tions in level XIV is problematic in chronological terms, given that levelXIV has to be before MIS 8 (level XII) (Richard et al., 2019). Due to its techno-typological implications, it will be necessary to determine by functional analysis if its use wear confirms its classification as strictly apoint or if it is a pointed element, with an elongated morphology, used as a knife. The high percentage of preferential Levallois flakes at levels XII-XIV are all found in an old context in which there are elements consistent with the previous chronology of these levels: presence of bifaces, limaces and Tayac points, among others. The wide thickness ofthese levels indicates we are facing an alternation of occupations with different technological systems, generating a lack of precision in the excavation and a false sense of palimpsest or mixture. The low density of lithic and bone remains, and the greater presence of Chiroptera co- prolites and neonatal individuals from these levels (Guillem, 2009; Villaverde et al., 2009), are consistent with the theory of sporadic oc- cupation, spaced in time and probably easy to differentiate in sequen- tial terms. Unfortunately, these levels have not been excavated in recent years except in the South sector, where only level XII provided asso- ciated lithic and faunal remains, documenting the presence of the Le- vallois technique. 


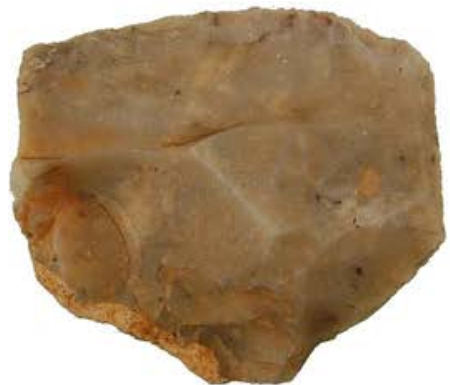

I

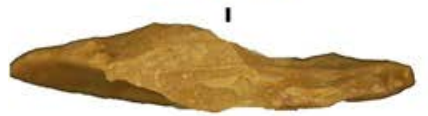

1

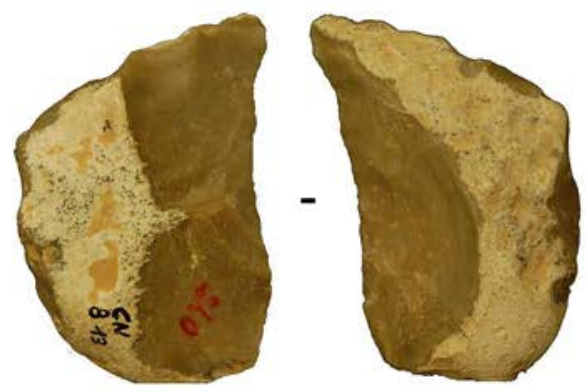

5
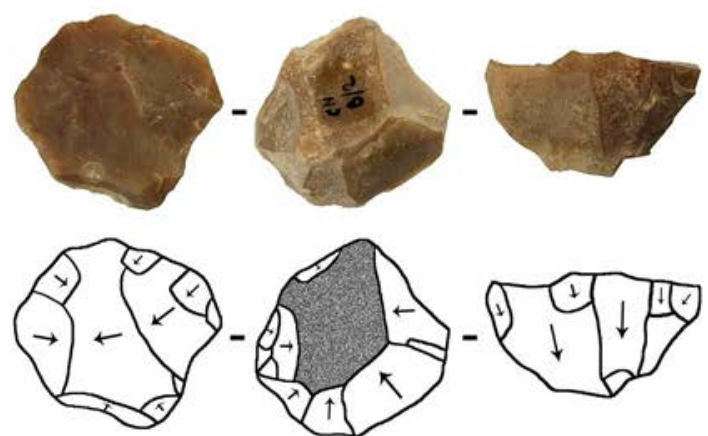

9

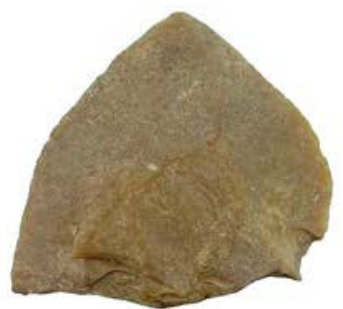

2

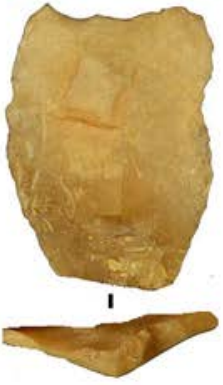

6

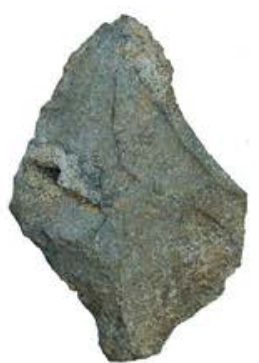

3

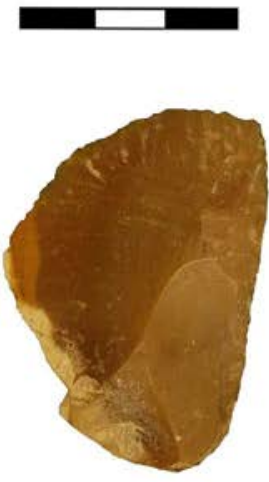

7

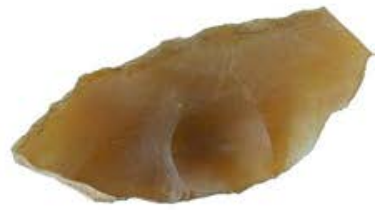

I

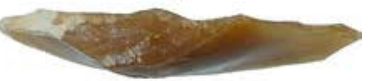

4

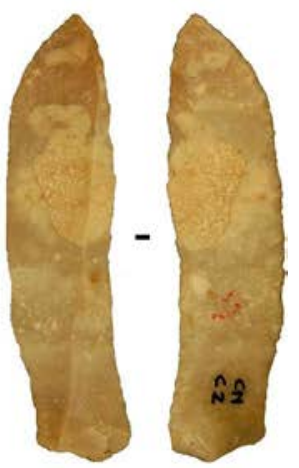

8 


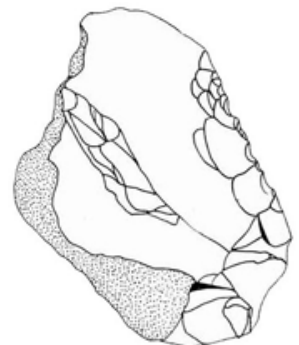

1

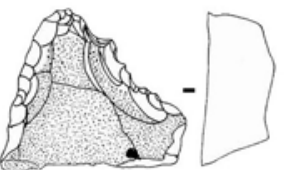

7

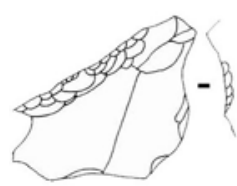

13

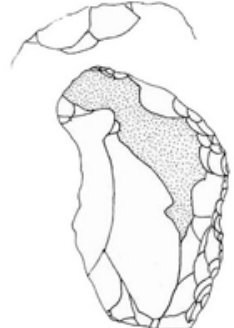

2

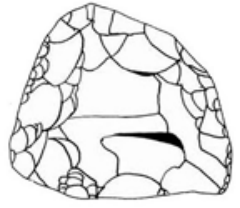

3

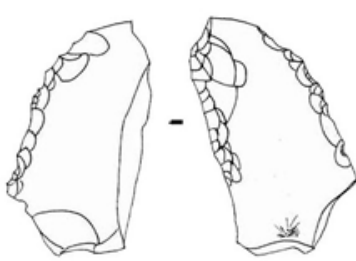

8

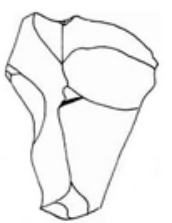

14

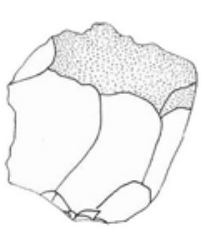

15

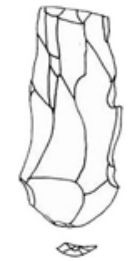

9

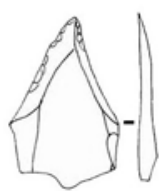

16

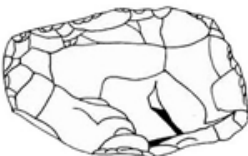

4

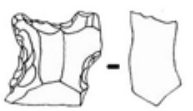

10

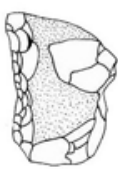

17

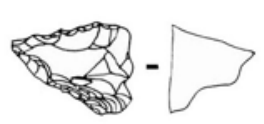

5

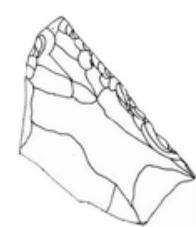

11

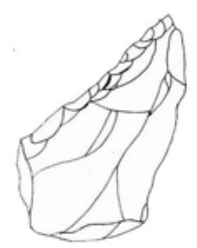

18

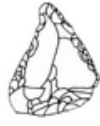

6

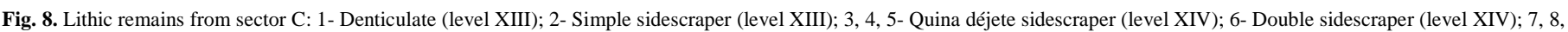

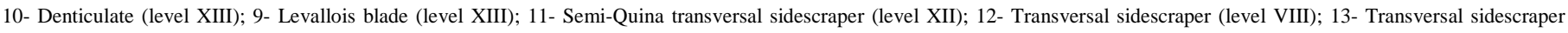

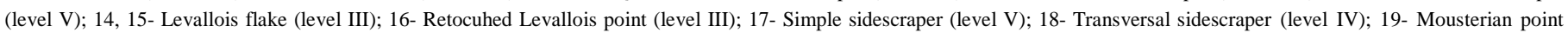
(level III).

3.2.2.1. Technology. The technological analysis shows the coexistence between typological Quina (sidescrapers with scaleriform retouch obtained from discoid strategies) and Levallois strategy in levels XIIto XIV, and the discoid and Levallois reduction methods in the upper sequence, especially in levels III and IV. It is worth mentioning the absence of the Levallois strategy at level VIII.

3.2.2.2. Typology. The denticulates are mostly linked to discoid knapping and acquire some importance from level XI to XIII and at levels III and IV. It is not possible to establish many diachronic variations, but it is worth noting the greater proportion of backed, convergent and déjeté sidescrapers in levels XI to XIII (Fig. 8).

Finally, it is important to note the Soyons points documented in the sequence have been linked to the removed upper level, which has materials from the Upper Palaeolithic and elements that correspond to the classical Middle Palaeolithic. In this case, given the advanced po- sition of this type of remain in other areas, they likely belong to the endof the Middle Palaeolithic.

\subsection{Sector $F$}

\subsubsection{Stratigraphy}

Sector $\mathrm{F}$ has been ordered in relation to the stratigraphic indications provided by the distal frontal profile in the West sector, and observationof the perfectly preserved left sagittal profile of sector F. Therefore, the sequence has been established from level I to XIV.

\subsubsection{Lithics}

The total number of remains distributed throughout the levels is 165, although the distribution is remarkably uneven. The absence of lithic evidence is concentrated in the basal levels (XII-XIV) and in level X, although the remaining materials barely exceed or remain below 20 elements, with level I being the only exception where it reaches 35 remains. The density analysis confirms what was seen in the previous two sectors analysed, and the absence of materials at levels X, XII, XIIIand XIV confirms that the occupation must have been sporadic and localised in the basal part of the sequence. We attribute these differ- ences to the variations in the occupied areas, although the same ab- sence or scarcity of materials is observed in the three sectors analysed here, which seems to indicate a particularly poor phase in the occupation.

3.3.2.1. Technology. In technological terms, level XI has similar number of blanks related to the Levallois method as the discoid. The typological and technological Quina elements are reduced, but they aredistributed throughout all levels, and the Levallois and discoid strategies coexist throughout all the levels in which industry has been documented. The exceptions, given the low number of remains, are not 


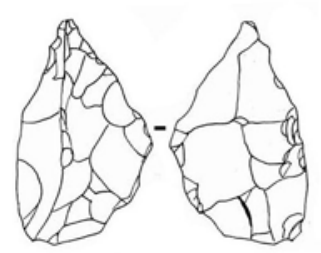

1

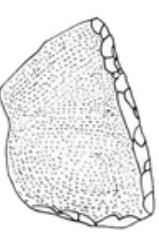

2

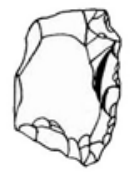

3

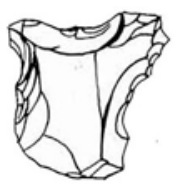

4

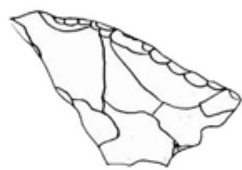

5

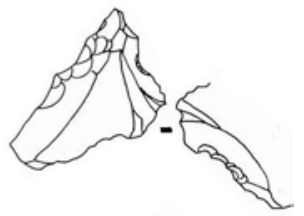

6

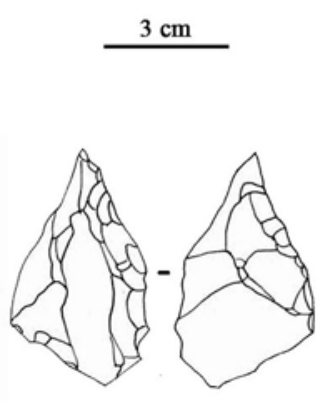

7

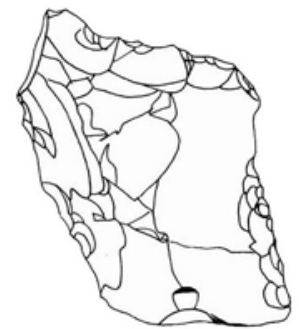

8

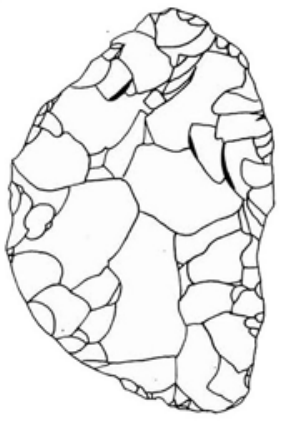

9

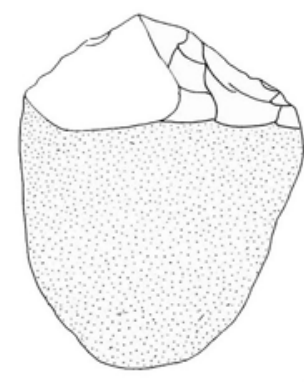

10

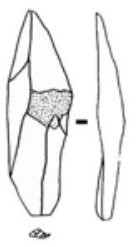

11

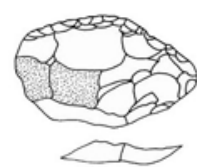

12

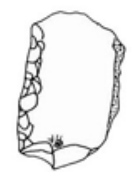

13

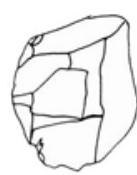

14

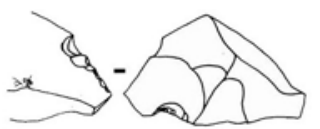

15

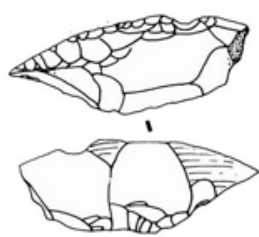

16

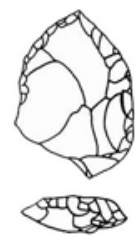

17

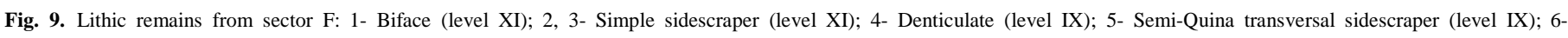

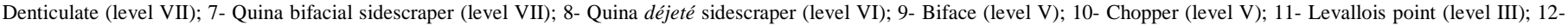

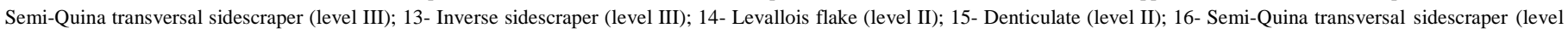
I); 17- Mousterian point (level I).

particularly relevant; there is no Levallois at levels V, VI and IX, andthere is no discoid at level IV (Fig. 9).

3.3.2.2. Typology. Regarding relevant remains, there is the presence of two bifaces, one at level V and one at XI. It is also important to highlight the association of denticulates with discoid blanks and the predominance of simple or transversal sidesrapers throughout the sequence, with a light presence of other types in this sector.

When considering the three sectors studied, it is appropriate to refer to the presence of the preferential Levallois reduction at some levels of the sequence. In total, the number of blanks linked to the Levallois strategy amounts to 215, of which 99 correspond to the preferential method (46\%). This proportion is especially high at some levels: at level IV, 13 of the 22 Levallois elements are preferential; level V, 18 of 24; level VII, 4 of 6; level XI, 4 of 7; level XII, 7 of 14; and level XIV, with 10 of the 20. Generally, it is uncommon to find the preferential Levallois reduction in a Mediterranean Iberian context, so this finding in a con- text that mostly refers to the final Middle Pleistocene (MIS 6 to 8 at levels V to XI) (Richard et al., 2019) must be taken into account for future assessments of the Levallois method.

\section{Conclusions}

The readjustment of the distribution of lithic materials from sectors B and C, excavated in 1950, and F, excavated in 1953, which we have carried out in this work is supported by a thorough study of the stra- tigraphic profiles closest to these sectors. This new research has allowed us to specify with greater certainty the techno-typological evolution ofthe Middle Palaeolithic from Cova Negra. The numbers of lithic evi-dence related to each stratigraphic unit has been reduced with respectto previous works, but provides a new chronological framework that reveals characteristics of the Lower Middle Palaeolithic at this site andin the Iberian

Peninsula Mediterranean region. It is important to highlight that, for the moment, the dates obtained through ESR levels Vto XI are correlated with the

Middle Pleistocene (MIS 6-8). New datesobtained through OSL will soon contribute clarifying the chronology ofthe upper and lower levels. By relative position with respect to avail-able dates, we think that levels XIII and XIV could correlate with MIS 9.The implications derived from this proposed new chronology not only affect the documented use of the Levallois technique and theQuina component industries in the chronological framework belongingto the Middle Pleistocene, but also have a profound impact on the

as- sessment of the human remains recovered at the site because a large number of these correlate a grosso modo with MIS 6-8.

The variations observed in the quantifications of the lithic remains and the densities of the different levels in the three sectors have con- firmed two aspects that were suggested in previous research: 1) human occupations were of low intensity and sporadic, and 2) the occupied spaces were reduced and probably varied depending on the topographyof the different units, essentially in relation to the presence of blocks ofa certain size detached from the roof of the cavity. It is difficult to specify the characteristics of these occupations because in the density of findings by sectors, not only the duration of the occupations and their frequency, but also the number of occupants and the tasks carried out in 
the cavity can join.

Another aspect that the three analysed sectors have confirmed is that the archaeological remains of human origin are lower in the basal levels, with an older chronology, and that the highest densities coincidewith levels VII to I, even though the information of levels I and II is limited to sector F.

The raw materials have a semi-local origin, and a study of the ma- terials show fragmented operative chains, with scant presence of cores and chips. This observation has also been recorded in recent excava- tions and, therefore, is not a consequence of the old excavation meth- odology. In West sector, for example, at level II, we find 3 chips and 1 thermal fragment, for a total of 7 pieces. The others are 2 flakes, 1 piece with lateral retouches and 1 sidescraper. At level III, 31 pieces are documented (5 sidescrapers, 2 backed knifes, 1 denticulate, 1 core fragment, 17 flakes and 5 chips). At level IV, 27 pieces, 12 flakes and 15 chips and at level V, 1 sidescraper, 1 denticulate, 2 flakes and 14 chips. As we can see, although the values reached by the chips are slightly higher than those recorded in the 1950s, the proportion of cores, chips or unretouched material, as we indicated, remains low with respect to what is usually observed in other sites. This confirms the fragmentation of the operational chains and coincides with the short duration of the occupations.

One of the most significant elements of this new stratigraphic study is associated with the early appearance of the Levallois technique, which presents especially high numbers of the preferential variant. Its presence in chronologies that point to MIS 8 (level XII) and probably MIS 9 considering their relative position with respect to level XII, co- incides with similar situations indicated on other sites within the Iberian Peninsula (Canal and Carbonell, 1989; Rodríguez, 2004; Fernández-Peris, 2007; Santonja and Pérez-González, 2010; Barrosoet al., 2011; Santonja et al., 2014).

From a technological point of view, two issues must be highlighted: 1) the association of the discoid strategy and Quina and denticulated com-ponents in all sectors seems to confirm their consistency in techno-typo-logical terms; and, 2) the presence in the lower levels of bifaces and tools belonging to an older typology, such as limaces and Tayac points. Theirnumber, although low, raises the possibility that some Acheulean techno-typological event, or at least the association of bifaces and an industry typical of the Middle Palaeolithic, could also be recorded for the Middle Pleistocene. In total, 19 bifaces have been documented in the Cova Negra sequence: 15 belonging to the 1950s excavations, and 4 from Gonzalo Viñes excavations, belonging to the 1930s. It is not easy to stablish the stratigraphic position of the pieces that do not correspond with the threesectors studied in this work. In any case, sectors B, C and F indicate that level XIV presents 3 bifaces, on levels XII and XI another 3 pieces and oneat level V. Other bifaces from sectors D and J1, and from Viñes' excava-tions confirm that around level $\mathrm{V}$, that must correspond to the end of the Middle Pleistocene, a considerable number of them are documented. Considering these data, it is evident that in the future we need to analyzein more detail the typology of these bifaces and assess the possibility thatMTA A could be considered in this part of the sequence.

Finally, it can be concluded that the ordering of the levels has al- lowed us to verify that the Soyons points are located in the upper levels. In some cases, they are found in the level removed from the top of the sequence, indicating that this level includes Late Middle Palaeolithic elements, which is not forced to think that it can correspond to MIS 3, as well as materials from different phases belonging to the Upper Palaeolithic, as has been discussed in a recent work (Villaverde and Eixea, 2017).
Peninsula. Quat. Int. 243, 105-126.

Bar-Yosef, O., Belfer-Cohen, A., 2013. Following Pleistocene road signs of human dis-persals across Eurasia. Quat. Int. 285, 30-43.

Barsky, D., 2013. The Caune de l'Arago stone industries in their stratigraphical context. C.R. Palevol 12, 305-325 2013.

Benito del Rey, L., 1982. Outils fracturés intentionnellement dans le Moustérien de la grotte de Las Grajas à Archidona (Málaga, Espagne). Bull. Soc. Prehist. Fr. 79, 231-239.

Boëda, E., Geneste, J.M., Meignen, L., 1990. Identification de chaînes opératoires lithi-ques du Paléolithique ancien et moyen. Paléo 2, 43-80.

Boëda, E., 1991. Approche de la variabilité des systèmes de production lithique des in- dustries du Paléolithique inférieur et moyen: chronique d'une variabilité attendue. Tech. Cult. 17-18, 37-86.

Bordes, F., 1988. Typologie du Paléolithique Ancien et Moyen. CNRS, Paris. Bourguignon, L., Delagnes, A., Meignen, L., 2006. Systèmes de production lithique, gestion des outillages et territoires au Paléolithique moyen: où se trouve la complexité? In: Astruc, L., Bon, F., Léa, V., Milcent, P., y Philibert (Eds.), Normes techniques et pratiques sociales. de la simplicité des outillages pré- et protohistoriques. XXVIe re- ncontres internationales d'archéologie et d'histoire d'Antibes. Éditions APDCA, Antibes, pp. 75-86.

Bourguignon, L., Djema, H., Bertran, P., Lahaye, Ch, Guibert, P., 2008. Le gisementSaalien de Petit-Bost (neuvic, dordogne). In: Jaubert, J., Bordes, J.-G., dir, Ortega I ( (Eds.), Les sociétés du Paléolithique dans un grand Sud-Ouest de la France: nouveauX gisements, nouveauX résultats, nouvelles méthodes, actes de la séance SPF (université BordeauX 1, Talence, 2006). Société préhistorique française (Mémoire 47), Paris, pp. $41-55$.

Brenet, M., 2011. Variabilité et signification des productions lithiques au Paléolithique moyen ancien. L'exemple de trois gisements de plein-air du Bergeracois (Dordogne,France). Ph.D. dissertation. (Université de BordeauX I).

Canal, J., Carbonell, E., 1989. Catalunya Paleolítica. Patronat Francesc Eiximenis, Girona.

Colonge, D., Jarry, M., Delfout, G., Fondeville, C., 2010. De la transition paléolithique inférieur-moyen dans la vallée de la Garon: l'Acheuléen supérieur de Raspide 2 (Blagnac, Haute-Garonne). Bull. Soc. Prehist. Fr. 107, 205-227.

Carmignani, L., Moncel, M.H., Fernandes, P., Wilson, S., 2017. Technological variability during the Early Middle Palaeolithic in Western Europe. Reduction systems and predetermined products at the Bau de l'Aubesier and Payre (South-East France). PloS One 12, e0178550.

Chévrier, B., 2006. De l'Acheuléen méridional au technocomplexe trifacial: la face cachéedes industries du Bergeracois. Gall. Prehist. 48, 207-252.

Delagnes, A., Jaubert, J., Meignen, L., 2007. Les technocomplexes du paléolithique moyen en Europe occidentale dans leur cadre diachronique et géographique. In: Vandermersh, B., Maureille, B. (Eds.), Les Néandertaliens. Biologie et cultures. CTHS, Paris, pp. 213-229.

De Lumley, H., Gregoire, S., Barsky, D., Batalla, G., Bailon, S., Belda, V., Briki, D., Byrne, L., DesclauX, E., El Guenouni, K., Fournier, A., Kacimi, S., Lacombat, F., de Lumley,M.A., Moigne, A.M., Moutoussamy, J., Paunescu, C., Perrenoud, C., Pois, V., Quiles, J., Rivals, F., Roger, T., Testu, A., 2004. Habitat et mode de vie des chasseurs paléolithiques de la Caune de l'Arago (600000-400000 ans). L'Anthropologie 108, 159-184.

Delpech, F., Geneste, J.M., Rigaud, J.P., Texier, P.J., 1995. Les industries antérieures à la dernière glaciation en Aquitaine septentrionale: chronologie, paléoenvironnements, technologie et économie de subsistance. Paléo 1, 133-163.

Eixea, A., 2015. Caracterización tecnológica y uso del espacio en los yacimientos del Paleolítico medio de la región central del Mediterráneo Ibérico. Universitat deValència. Ph.D. dissertation.

Fernández-Peris, J., 2007. La cova del Bolomor (Tavernes de la Valldigna, Valencia). Las industrias líticas del Pleistoceno medio en el ámbito del Mediterráneo peninsular. Trabajos Varios del S.I.P 108 (Valencia).

Fontana, F., Moncel, M.-H., Nenzioni, G., Onorevoli, G., Peretto, C., Combier, J., 2013. Widespread diffusion of technical innovations around 300,000 years ago in Europe asa reflection of anthropological and social transformations? New comparative data

\section{References}

Baena, J., Torres, C., Sharon, G., 2018. Life history of a large flake biface. Quat. Sci. Rev. 190, 123-136.

Barroso Ruíz, C., Botella Ortega, D., Caparrós, M., Moigne, A.M., Celiberti, V., Testu, A., Barsky, D., Notter, O., Riquelme Cantal, J.A., Pozo Rodríguez, M., Carretero León, M.I., Monge Gómez, G., Khatib, S., Saos, T., Gregoire, S., Bailón, S., García Solano, J.A., Cabral Mesa, A.L., Djerrab, A., Hedley, I.G., Abdessadok, S., Batalla Llasat, G. Astier, N., Bertin, L., Boulbes, N., Cauche, D., FilouX, A., Hanquet, C., Milizia, C., Moutoussamy, J., Rossoni, E., Verdú Bermejo, L., de Lumley, H., 2011. The Cueva del Ángel (Lucena, Spain): an Acheulean hunters habitat in the South of the Iberian 
from the western Mediterranean sites of Orgnac (France) and Cave dall'Olio (Italy). J. Anthropol. Archaeol. 32, 478-498.

Fumanal, M.P., 1986. Sedimentología y clima en el País Valenciano. Trabajos Varios delS.I.P., 83 (Valencia)

Fumanal, M.P., Villaverde, V., 1997. Quaternary deposits in caves and shelters in thecentral Mediterranean area of Spain. L'Anthropologie (Brno) 35, 109-118.

Fumanal, M.P., Villaverde, V., 2009. Las excavaciones en la Cova Negra en los añós 80, la estratigrafía y el marco cronológico. In: Villaverde, V., Perez Ballester, J., Ledo, A. (Eds.), Historia de Xàtiva. Prehistoria, Arqueología y Antiguedad I Universitat de València.

Gagnepain, J., Gaillard, C., 2005. La grotte de la Baume Bonne (Quinson, Alpes-de-HauteProvence): synthèse chronostratigraphique et séquence culturelle d'après les fouilles récentes (1988-1997). In: Molines, N., Moncel, M.-H., Monnier, J.-L. (Eds.), Colloque international Données récentes sur les modalités de peuplement et sur le cadre chronostratigraphique, géologique et paléogéographique des industries du Paléolithique ancien et moyen en Europe. British Archaeological Reports, International Series S1364, pp. 73-87.

Grimaldi, S., 1998. Analyse technologique, chaîne opératoire et objectifs techniques. Torre in Pietra (Rome, Italie). Paléo 10, 109-122.

Guillem, P., 2009. Los micromamíferos (rodentia, insectivora y Chiroptera). In: Villaverde, V., Pérez Ballester, J., Ledo, A. (Eds.), Historia de Xàtiva. Prehistoria, Arqueología y Antigüedad. Universitat de València, Xàtiva, pp. 85-114.

Herisson, D., Brenet, M., Cliquet, D., Moncel, M.-H., Richter, J., Scott, B., Van Baelen, A.,Di Modica, K., De Loecker, D., Asthon, N., Bourguignon, L., Delagnes, A., Faivre, J.-P., Folgado, M., Locht, J.-L., Pope, M., Raynal, J.-P., Roebroeks, W., Santagata, C., Turq,A., Van Peer, P., 2016. The emergence of the Middle Palaeolithic in north-western Europe and its southern fringes. Quat. Int. 411, 233-283.

Jaubert, J., 1999. Chasseurs et artisans du Moustérien. La Maison des Roches, Paris.

Jaubert, J., 2002. Les sociétés du Paléolithique Moyen en France. PrincipauX acquis de ces dix derniéres années. Zephyrus LIII-LIV, 153-172.

Jiménez-Arenas, J.M., Santonja, M., Botella, M., Palmqvist, P., 2011. The oldest handaxes in Europe: fact or artefact? J. Archaeol. Sci. 38, 3340-3349.

Julien, M., 1992. Du fossile directeur a la chaînes opératoires. In: Garanger, J. (Ed.), La Prehistoire dans le monde. Nouvelle Clio, Paris, pp. 163-193.

Karlin, C., Bodu, P., Pelegrin, J., 1991. Processus techniques et chaînes opératoires. Comment les préhistoriens s'approprient un concept élaboré par les ethnologues. In: Balfet, H. (Ed.), Observer l'action technique: des chaînes opératoires, pour quoi faire?Editions du CNRS, Paris, pp. 101-117.

Lemonnier, P., 1986. The study of material culture today: toward an anthropology oftechnical systems. J. Anthropoogical Archaeol. 5, 147-186.

Méndez-Quintas, E., Demuro, M., Arnold, L., Duval, M., Pérez-González, A., Santonja, M., 2019. Insights into the late stages of the acheulean technocomplex of western iberiafrom the arbo site (Galicia, Spain). J. Archaeol. Sci.: Report 27, 101934.

Moncel, M.-H., 1995. Biface et outil-biface du Paléolithique moyen ancien : Réflexion à partir des sites d'Ardèche-Orgnac 3 et Payre. Paléo 7, 157-169.

Moncel, M.-H., 1999. Les assemblages lithiques du site Pléistocène moyen d'Orgnac 3(Ardèche, Moyenne Vallée du Rhône, France). Contribution à la connaissance du Paléolithique moyen ancien et du comportement technique différentiel des Hommes au Paléolithique inférieur et au Paléolithique moyen. ERA 89 (Liège).

Moncel, M.-H., 2003. L'exploitation de l'espace et la mobilité des groupes humains au travers des assemblages lithiques à la fin du Pléistocène moyen et au début du Pléistocène supérieur. La moyenne vallée du Rhône entre Drôme et Ardèche. Br. Archaeol. Rep. Int. Series S1184.

Moncel, M.-H., Moigne, A.-M., Combier, J., 2005. Pre-Neandertal behavior during iso- topic stage 9 and the beginning of stage 8: new data concerning fauna and lithics in the different occupation levels of Orgnac 3 (Ardèche, South-East France): occupationtypes. J. Archaeol. Sci. 32, 1283-1301.

Moncel, M.-H., Moigne, A.-M., Youssef, S., Combier, J., 2011. The emergence of nean- derthal technical behavior: new evidence from orgnac 3 (level 1, MIS 8), southeastern France. Curr. Anthropol. 52, 37-75.

Moncel, M.-H., Moigne, A.-M., Combier, J., 2012. Towards the Middle palaeolithic inwestern Europe: the case of orgnac 3 (southeastern France). J. Hum. Evol. 63, 653-666.

Ollé, A., Mosquera, M., Rodríguez, X.P., de Lombera-Hermida, A., García-Antón, M.D., GarcíaMedrano, P., Peña, L., Menéndez, L., Navazo, M., Terradillos, M., Bargalló, A., Márquez, B., Sala, R., Carbonell, E., 2013. The early and Middle Pleistocene technological record from Sierra de Atapuerca (Burgos, Spain). Quat. Int. 295, 138-167.

Ollé, A., Mosquera, M., Rodríguez-Álvarez, X.P., García-Medrano, P., Barsky, D., de Lombera-Hermida, A., Carbonell, E., 2016. The Acheulean from Atapuerca: three steps forward, one step back. Quat. Int. 411, 316-328.

Picin, A., Peresani, M., Falguères, C., Gruppioni, G., Bahain, J.-J., 2013. San Bernardinocave (Italy) and the appearance of Levallois technology in Europe: results of a radiometric and technological reassessment. PloS One 14, e76182.
Piperno, M., Biddittu, I., 1978. Studio tipologico ed interpretazione dell'industria acheuleana e pre-musteriana dei livelli m e d di Torre in Pietra (Roma) in Torre in Pietra (Roma). Quaternaria 20, 441- 536.

Peretto, C., Arzarello, M., Bahain, J .-J ., Boulbes, N., Dolo, J.-M., Douville, E., Falguères, C., Frank, N., Gracía, T., Lembo, G., Mpigne, A.M., Muttillo, B., Nomade, S., Pereira, A., Rufo, M.A., Sala, B., Shao, Q., Hohenstein, U.T., Tessari, U., Turrini, M.C. Vaccaro, C., 2016. The Middle Pleistocene site of Guado san Nicola (Monteroduni, Central Italy) on the lower/middle palaeolithic transition. Quat. Int. 411, 301-315.

Richard, M., Falguères, C., Pons-Branchu, E., Foliot, L., Guillem, P.M., Martínez-Valle, R., EiXea, A., Villaverde, V., 2019. ESR/U-series chronology of early neanderthal occupations at cova Negra (Valencia, Spain). Quat. Geochronol. 49, 283- 290.

Richter, J., 2011. When did the Middle Palaeolithic begin? In: Conard, N.J., Richter, J. (Eds.), Neanderthal Lifeways, Subsistence and Technology: One Hundred Fifty Years of Neanderthal Study, Vertebrate Paleobiology and Paleoanthropology. Springer Science Business Media B.V, pp. 7- 14

Rodríguez, X.P., Lozano, M., 1999. El Pleistoceno medio y superior inicial del noreste de la Península Ibérica. Pyrenae 30, 39-68.

Rodríguez, X.P., 2004. Technical systems of lithic production in the lower and Middle Pleistocene of the Iberian Peninsula: technological variability between northeastern sites and Sierra de Atapuerca sites. Bar Int. 1323.

Santonja, M., Pérez-González, A., 2006. La industria lítica del miembro estratigráfico medio de Ambrona (Soria, España) en el contexto del Paleolítico Antiguo de la Península Ibérica. Zephyrus LIX, 7- 20.

Santonja, M., Pérez-González, A., 2010. Mid-pleistocene acheulean industrial complex in the Iberian Peninsula. Quat. Int. 223-224, 154- 161.

Santonja, M., Pérez-González, A., Domínguez- Rodrigo, M., Panera Gallego, J., Rubio Jara, S., Sesé, C., Soto Rodríguez, E., Arnold, L., Duval, M., Demuro, M., Ortiz Menéndez, J.E., Torres, T., Mercier, N., Barba, R., Yravedra, J., 2014. The Middle paleolithic site of Cuesta de la Bajada (Teruel, Spain): a perspective on the acheulean and Middle paleolithic technocomplexes in Europe. J. Archaeol. Sci. 49, 556- 571.

Santonja, M., Pérez-González, A., Panera, J., Rubio-J ara, S., Méndez-Ouintas, E., 2016. The coexistence of acheulean and ancient Middle palaeolithic techno-complexes in the Middle Pleistocene of the Iberian Peninsula. Quat. Int. 411, 367- 377.

Scott, B., 2010. Becoming Neanderthals. The Earlier British Middle Palaeolithic. Oxbow Books, Oxford and Oakville.

Sharon, G., 2010. Large flake acheulian. Quat. Int. 223- 224, 226- 233.

Sharon, G., 2011. Flakes crossing the straits? Entame flakes and northern africa-iberia contact during the acheulian. African Archaeol. Rev. 28, 125- 140.

Sharon, G., Barsky, D., 2016. The emergence of the Acheulian in Europe- a look from the east. Quat. Int. 411, 25- 33.

Soriano, S., Villa, P., 2017. Early Levallois and the beginning of the Middle paleolithic in central Italy. PloS One 12, e0186082.

Texier, P.J., 1996. Evolution and diversity in flaking techniques and methods in the Palaeolithic. In: Anati, E. (Ed.), Oltre la pietra. Modelli e tecnologie per capire la Preistoria. Abaco Edizioni. Forli, pp. 297- 321.

Tixier, J., Inizan, M.L., Roche, H., 1980. Préhistoire de la pierre taillé. 1. Terminologie et technologie. Cercle des recherches et études préhistoriques, Valbonne.

Turq, A., 1992. Le Paléolithique inférieur et moyen entre les vallées de la Dordogne et du Lot. Habilitation à diriger des recherches. Université de BordeauX.

Turq, A., 2000. Paléolithique inférieur er mayen entre Lot et Dordogne. Paléo supplément na 2.

Villa, P., 2009. The lower to Middle paleolithic transition. In: Camps, M., Chauhan, P. (Eds.), Sourcebook of Paleolithic Transitions, Methods, Theories, and Interpretations. Springer, New York, pp. 265-270.

Villaverde, V., 1984. La Cova Negra de Xàtiva y el musteriense de la región central del mediterráneo español. Trabajos Varios del S.I.P 79 (Valencia).

Villaverde, V., Martínez-Valle, R., Guillem, P., Fumanal, M.P., 1996. Mobility and the role of small game in the Middle paleolithic of the central region of the Spanish Mediterranean: a comparison of cova Negra with other paleolithic deposits. In: Carbonell, E., Vaquero, M. (Eds.), The Last Neandertals the First Anatomically Modern Humans. Cultural, Change and Human Evolution: the Crisis at 40 KA BP. Universitat Rovira i Virgili, Tarragona, pp. 267- 288.

Villaverde, V., Martínez Valle, .R., Blasco, R., 2009. Análisis de la industria lítica y de la economía: aproXimación al uso del espacio. In: In: Villaverde, V., Pérez Ballester, J., Ledo, A. (Eds.), Historia de Xàtiva. Prehistoria, Arqueología y Antiguedad, vol. I. Universitat de València, pp. 147- 193.

Villaverde, V., Guillem, P.M., Martínez-Valle, R., Eixea, A., 2014. Cova Negra. In: Sala, R. (Ed.), Pleistocene and Holocene Hunter-Gatherers in Iberia and the Gibraltar Strait. The Current Archaeological Record. Universidad de Burgos, Fundación Atapuerca, pp. 361- 369 .

Villaverde, V., EiXea, A., 2017. Materiales del Paleolítico superior en Cova Negra (Xàtiva) y su interés para establecer los procesos de su secuencia estratigráfica. Zephyrus LXXX, 15- 32. 